\title{
Balancing groundwater conservation and rural livelihoods under water and climate uncertainties: An integrated hydro-economic modeling framework
}

\author{
Consuelo Varela-Ortega ${ }^{\mathrm{a}, *}$, Irene Blanco-Gutiérrez ${ }^{\mathrm{a}, 1}$, Christopher H. Swartz ${ }^{\mathrm{b}, 2}$, Thomas E. Downing ${ }^{\mathrm{c}, 3}$ \\ ${ }^{a}$ Department of Agricultural Economics and Social Sciences. Universidad Politécnica de Madrid, Madrid, Spain \\ ${ }^{\mathrm{b}}$ Stockholm Environment Institute, US Center, Somerville, MA, USA \\ 'Stockholm Environment Institute, Oxford Office, Oxford, UK
}

Keywords:

Water policies

Agricultural policies

Economic model

Hydrology model

Integrated modeling

Climate uncertainty

\begin{abstract}
A B S T R A C T
In arid countries worldwide, social conflicts between irrigation-based human development and the conservation of aquatic ecosystems are widespread and attract many public debates. This research focuses on the analysis of water and agricultural policies aimed at conserving groundwater resources and maintaining rural livelihoods in a basin in Spain's central arid region. Intensive groundwater mining for irrigation has caused overexploitation of the basin's large aquifer, the degradation of reputed wetlands and has given rise to notable social conflicts over the years. With the aim of tackling the multifaceted socio-ecological interactions of complex water systems, the methodology used in this study consists in a novel integration into a common platform of an economic optimization model and a hydrology model WEAP (Water Evaluation And Planning system). This robust tool is used to analyze the spatial and temporal effects of different water and agricultural policies under different climate scenarios. It permits the prediction of different climate and policy outcomes across farm types (water stress impacts and adaptation), at basin's level (aquifer recovery), and along the policies' implementation horizon (short and long run). Results show that the region's current quota-based water policies may contribute to reduce water consumption in the farms but will not be able to recover the aquifer and will inflict income losses to the rural communities. This situation would worsen in case of drought. Economies of scale and technology are evidenced as larger farms with cropping diversification and those equipped with modern irrigation will better adapt to water stress conditions. However, the long-term sustainability of the aquifer and the maintenance of rural livelihoods will be attained only if additional policy measures are put in place such as the control of illegal abstractions and the establishing of a water bank. Within the policy domain, the research contributes to the new sustainable development strategy of the EU by concluding that, in water-scarce regions, effective integration of water and agricultural policies is essential for achieving the water protection objectives of the EU policies. Therefore, the design and enforcement of well-balanced region-specific polices is a major task faced by policy makers for achieving successful water management that will ensure nature protection and human development at tolerable social costs. From a methodological perspective, this research initiative contributes to better address hydrological questions as well as economic and social issues in complex water and human systems. Its integrated vision provides a valuable illustration to inform water policy and management decisions within contexts of water-related conflicts worldwide.
\end{abstract}

1. Introduction: Policy drivers for irrigation development and ecosystem conservation

Competing access to water resources among sectors and regions and derived social conflicts are widespread throughout arid and semiarid countries worldwide. One of the world examples is the Mediterranean basin in which irrigation expansion has been a key driver for developing the agricultural sector and rural livelihoods (Benoit and Comeau, 2005). Alongside with the development of publicly funded surface irrigation networks and water storage infrastructure, groundwater irrigation has expanded 
progressively under private initiatives by a countless number of individual farmers. This has been the case of Spain's Mediterranean littoral and its southern hinterland, where groundwater is the main source of water for irrigation. Its mounting expansion over the last decades has been the response of easily accessible modern drilling and pumping technologies for many individual farmers, low cost of irrigation equipment, lucrative farming activities and the higher resilience of subterranean waters to climate variability (Llamas and Martínez-Santos, 2006; Mukherji, 2006; Varela-Ortega, 2007). However, groundwater based economic and social development has come along with significant environmental damage to aquatic ecosystems giving rise to acute social conflicts as environmental awareness expands progressively in society (Rosegrant et al., 2002; CAWMA, 2007; Varela-Ortega, in press).

The Upper Guadiana basin in Spain's inland region of Castilla La Mancha (see Fig. 1) provides an illustrative example of water related conflicts that have persisted over the years.

On the one hand, intensive use of groundwater has offset the everlasting drought problems in the area and has given rise to an irrigation-based thriving economy of a once stagnated region. On the other hand, water pumping has led to the overexploitation of the region's large aquifer 'Western La Mancha' (which spans over an area of $5000 \mathrm{~km}^{2}$, see Fig. 1), and the progressive degradation of the nearby internationally reputed wetlands of the national park 'Tablas de Daimiel', catalogued in the Ramsar list and a UNESCO Biosphere reserve (Baldock et al., 2000; MIMAM, 2006; Ramsar, 2006). In the last 30 years, the aquifer levels dropped an average of $30 \mathrm{~m}$ in some areas, resulting in a total storage depletion of about 3000 million $\mathrm{m}^{3}$ and a dramatic reduction of the flooded wetland area from 1800 ha to less than 200 ha (one-tenth of its original coverage) (CHG, 2007a). Salinization and contamination affected groundwater quality and eutrophication of surface water flows brought about changes in the autochthonous vegetation and pit fires emerged as flooded surface remitted in the wetland (MIMAM, 2006; Martínez-Santos et al., 2008). Farmers that wished to continue pumping and expand irrigation clashed with the basin's Water Authority trying to put a halt to the persistent water mining.

In the Upper Guadiana, as in other irrigated areas in Spain, water policies and agricultural policies have determined directly and indirectly, water consumption. Strong evidence supports that irrigation expansion has been and still is, primarily, a policy-driven outcome (Varela-Ortega, 2007). Past programs of the Common Agricultural Policy (CAP), during the 80's and 90's, included subsidies to the farmers that were based on crop yields, meaning that subsidies were coupled to production. Hence, irrigated crops with higher yields benefited from higher subsidies and irrigation intensification was encouraged. As a result, overpumping occurred in the Western La Mancha aquifer and overall abstractions reached up to 500 million $\mathrm{m}^{3}$ surpassing its natural recharge rate set at 230 million $\mathrm{m}^{3}$ (CHG, 2006). As return flows diminished and the water table lowered considerably, the aquifer was declared officially overexploited in 1991 (MOPTMA-CHG, 1995).

With the aim of finding a remedy to the overexploitation of the aquifer, the River Basin Authority (RBA) adopted a Water Abstraction Plan (WAP) in 1991 based on the imposition of a strict water quota regime with no compensation to the farmers for their derived income loss. Water quotas were established based on farm size, larger farms having a smaller volume. The quotas reduced considerably the entitled historical water rights of the irrigators from an average of $4200 \mathrm{~m}^{3}$ /ha to $2000 \mathrm{~m}^{3} /$ ha (CHG, 2006). This policy has created a long-lasting social unrest and freeriding behavior among irrigators with uncontrolled drillings. The Water Administration has not been capable of enforcing the policy to its full application, due to the large social costs implied for monitoring and controlling the actual water volumes extracted by the farmers. This situation is common to other world examples (Guerrero-García et al., 2008, in Mexico; Mukherji, 2006 in India; Qureshi et al., 2009, in Pakistan; Varela-Ortega and Sagardoy, 2003; in Syria; Zekri, 2009, in Oman; among others) and exemplifies the difficulty in controlling groundwater drilling in

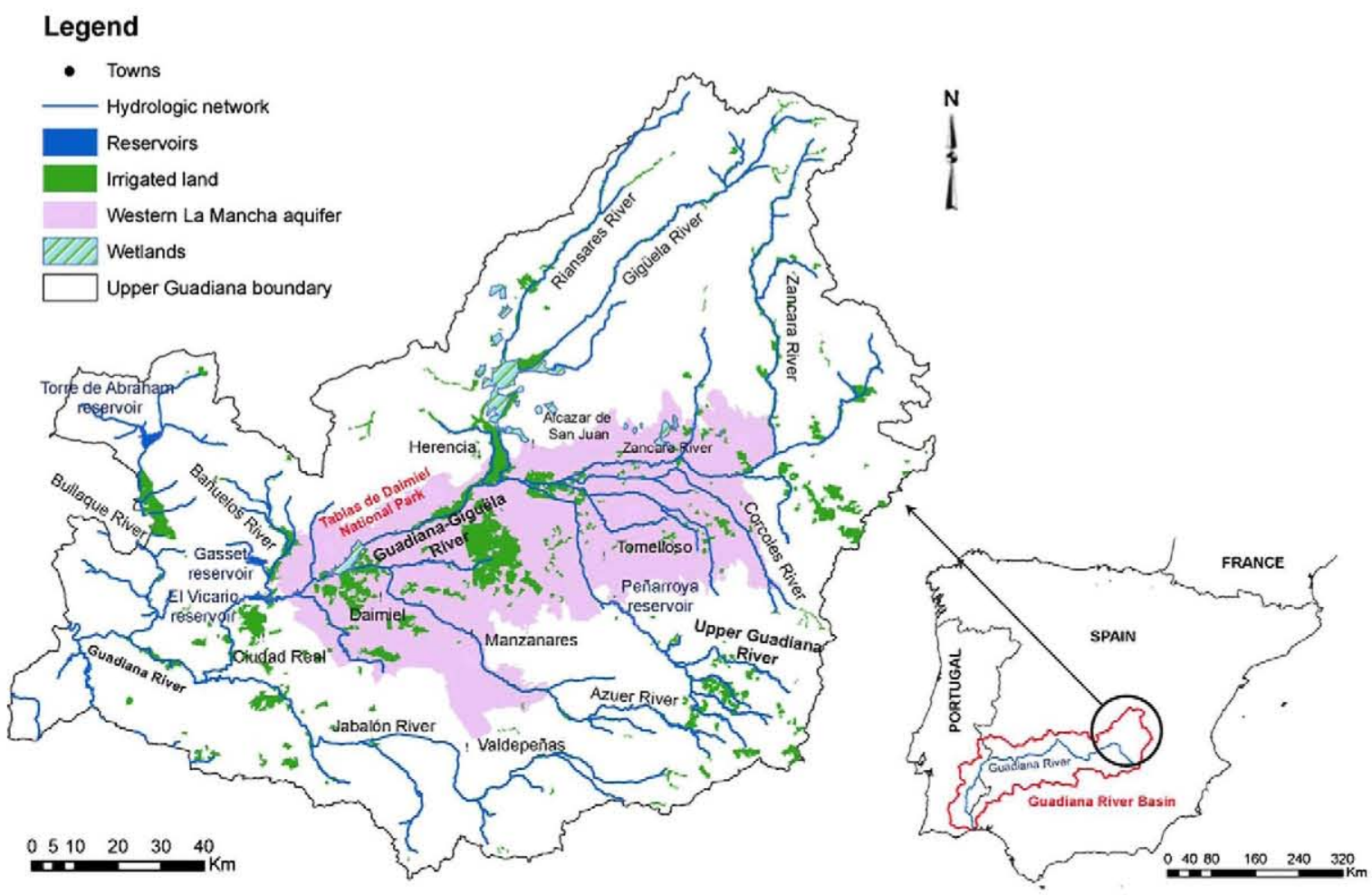

Fig. 1. Geographical setting of the Upper Guadiana basin. 
an open-access common-pool resources structure, as it entails high enforcement costs to the public authorities (Provencher and Burt, 1994; Shah et al., 2000; Schuyt, 2005; Schlager and LópezGunn, 2006; Llamas and Martínez-Santos, 2006; McCann et al., 2005).

In parallel, as the CAP evolved to include progressively environmental considerations, a special 5-year Agri-Environmental Program (AEP) was launched in the area following the CAP reform of 1992. The AEP established a system of water quotas that reduced the farmers' entitled water volumes (by $50 \%, 70 \%$ or $100 \%$ ) and a correspondent payment which compensated the farmers for their derived income if they joined voluntarily the program. The AEP was extended up to 2002 and was joined by a majority of the irrigators, covering an overall area in the mid 1990s close to 100,000 ha (out of the 150,000 total irrigated lands) and met, consequently, the objectives of reducing the annual water abstractions to about 270 million $\mathrm{m}^{3}$ (below the 320 million $\mathrm{m}^{3}$ target) (JCC-LM, 1999). However, the program entailed high public costs due to the compensation payments, a considerable burden to the EU budget and its cost-effectiveness was questioned (Iglesias, 2001; Varela-Ortega, 2007). In 2003 the AEP program was reformed responding to the increasing environmental concerns within the CAP. Water quotas were reduced further with respect to the irrigators' initial water rights as percent volume reductions were based on the existing national WAP quotas. The EU AEP policy and the national WAP were joined for the first time under a common objective for recovering the Western La Mancha aquifer. In the new AEP, income compensation payments were barely covering farm income loss from less water being available for farming. Therefore, the program was abandoned by a large proportion of the farmers and extended over just about 19,000 ha (CHG, 2006) which made the program no longer valid for accomplishing the water mining reductions target in the overall aquifer. Fig. 2 shows the evolution of water abstraction, irrigated surface and irrigated land joining the AEP program from the mid 1980 s to 2009 and the temporal overlapping sequence of the policy programs that were applied in the area.
The CAP evolved along the course of the years and has included progressively environmental requirements for ecosystem protection into its crop support programs. Different reforms followed. The reform that was in force up to 2009 , the so-called Luxembourg reform (2003-2009), had adapted to international trade agreements and the subsidies, or direct payments to farmers, were partially or totally decoupled from production to avoid market distortions. In addition, these payments are tied to environmental requirements by which the farmers that receive them are obliged to comply with specific environmental standards under a 'crosscompliance' regulation. Following, the new CAP 'health check', starting in 2010, has strengthen the compliance with environmental conditions whereas direct payments granted to farmers are fully decoupled from production in the form of a single farm payment (EC, 2009).

From the side of the EU water policies, the EUWater Framework Directive, enacted in 2000 is the first comprehensive basin-based integrated water policy in Europe (EC, 2000). It requires all Member States to achieve 'good ecological status' of all watercourses by 2015 (or 2027 to the latest) and develop specific river basin management plans in all basins across the EU by 2009 with public participation and direct stakeholder involvement. In the Guadiana basin, the WFD initiative requires the RBA to achieve the aquifer's recharge by 2027 , which sets the maximum annual water volume diverted to the agricultural sector in 200 million $\mathrm{m}^{3}$. In line with this EU policy, the RBA launched in 2007 a regional water plan, the Special Plan for the Upper Guadiana (SPUG), with the aim of recovering the over-drafted Western La Mancha aquifer (CHG, 2007a). The SPUG includes different types of measures, such as purchasing water rights from the irrigators in the newly created Water Rights Exchange Center, a social restructuring plan that includes the legalization of illegal wells, the closing-up of unlicensed bores, a reforestation plan and the support of extensive rainfed farming.

Over the years, agricultural policies and water policies, both EU and regional, have merged progressively into common objectives of natural resources conservation. One example is the last reform of the CAP (the 'Health Check' reform) which makes a

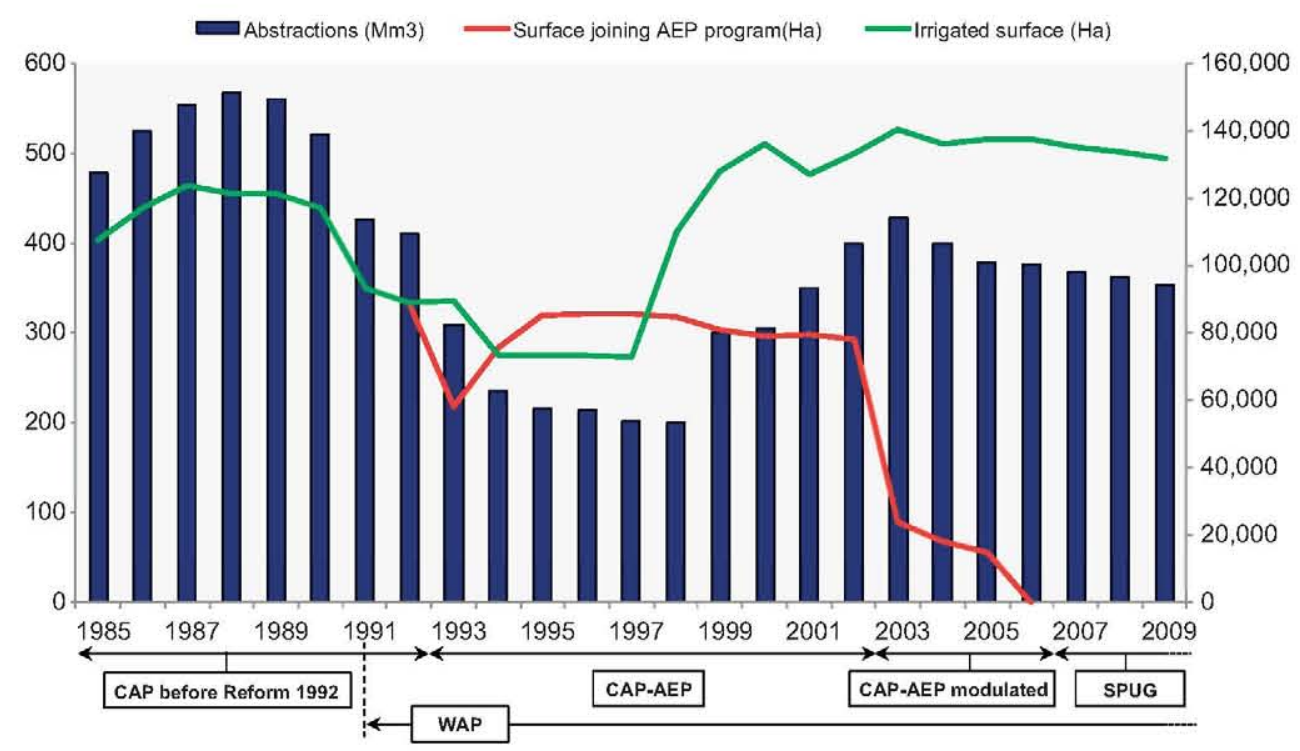

Notes: CAP (Common Agricultural Policy); WAP (Water Abstraction Plan); AEP (Agri-Environmental Program); SPUG (Special Plan for the Upper Guadiana). Mm3 (Million cubic meters)

Source: Updated from Varela-Ortega (2007). 
step forward into this direction by including water management and climate change as specific requirements in its programs (EC, 2009). Yet, the CAP requires also meeting socio-economic goals to ensure a sustainable, competitive and multifunctional agriculture. Integrating environmental, economic and social objectives of agricultural and water policies has become a major challenge for adapting to new forms of water management in the EU policy context.

Table 1 gives a summarized overview of the main agricultural and water policies that were applied in the area. The table includes the objectives of each policy, its main characteristics and the indicators that are relevant for policy analysis from the economic, social and environmental perspective ( such as farm income, public expenditure, crop distribution, water consumption, and groundwater storage in the aquifer).

\section{Integration of socio-economic processes with natural systems in water resources management: $A$ modeling approach}

The Upper Guadiana basin provides an illustrative example of the difficulties encountered to balance effectively groundwater deliveries for maintaining an irrigation-based rural economy and the conservation of the Western La Mancha aquifer. The longlasting lack of integration and mismatching of agricultural policies

Table 1

Agricultural policies and water policies in the area of study.

\begin{tabular}{|c|c|c|c|c|c|}
\hline & Type of policy & Scope & Policy objective & Policy characteristics & $\begin{array}{l}\text { Relevant indicators } \\
\text { for policy analysis }\end{array}$ \\
\hline \multirow[t]{11}{*}{$\begin{array}{l}\text { Agricultural } \\
\text { policies }\end{array}$} & $\begin{array}{l}\mathrm{CAP}^{(\mathrm{a})}-1992 \text { Reform \& } \\
\text { Agenda } 2000\end{array}$ & $\begin{array}{l}\text { European } \\
\text { Union }\end{array}$ & $\begin{array}{l}\text { - Farm income stability } \\
\text { - Environmental protection }\end{array}$ & $\begin{array}{l}\text { - Direct payments totally linked to } \\
\text { agricultural production volumes }\end{array}$ & $\begin{array}{l}\text { - Farm income } \\
\text { - Water consumption } \\
\text { - Crop distribution } \\
\text { - Public expenditure }\end{array}$ \\
\hline & $\begin{array}{l}\text { CAP }^{(a)}-A E P \\
\text { (Agri-Environmental } \\
\text { Program) 1993-2006 }\end{array}$ & & & $\begin{array}{l}\text { - Water quotas (1993-2002 reduction } \\
\text { from original water allotments; } \\
2003-2006 \\
\text { reduction from permitted abstraction } \\
\text { volumes of the WAP) }\end{array}$ & - Farm income \\
\hline & & & $\begin{array}{l}\text { - Reduce agricultural water } \\
\text { consumption }\end{array}$ & - Income compensation payments & - Water consumption \\
\hline & & & $\begin{array}{l}\text { - Wetland recovery } \\
\text { - Farm income stability }\end{array}$ & - Voluntary & $\begin{array}{l}\text { - Crop distribution } \\
\text { - Groundwater storage } \\
\text { - Public expenditure }\end{array}$ \\
\hline & $\begin{array}{l}\text { CAP }^{(a)} \text { - Luxembourg } \\
\text { Reform 2003-2010 }\end{array}$ & & - Competitive agriculture & $\begin{array}{l}\text { - Partial decoupling (direct payments } \\
\text { partially linked to agricultural } \\
\text { production volumes) }\end{array}$ & - Farm income \\
\hline & & & - Farm income stability & $\begin{array}{l}\text { - Cross Compliance schemes (payments } \\
\text { subject to compliance with } \\
\text { environmental regulations) }\end{array}$ & - Water consumption \\
\hline & & & $\begin{array}{l}\text { - Environmental sustainability } \\
\text { - Rural development }\end{array}$ & - Rural development programs & $\begin{array}{l}\text { - Crop distribution } \\
\text { - Public expenditure }\end{array}$ \\
\hline & $\begin{array}{l}\text { CAP }^{(a)} \text {-'Health Check' } \\
\text { Reform } 2010\end{array}$ & & - Market-oriented agriculture & $\begin{array}{l}\text { - Full decoupling (subsidies not linked } \\
\text { to agricultural production volumes) }\end{array}$ & - Farm income \\
\hline & & & - Rural communities sustainability & $\begin{array}{l}\text { - Cross-compliance schemes and new } \\
\text { requirements for water management }\end{array}$ & - Farmers' vulnerability \\
\hline & & & $\begin{array}{l}\text { - Maintain rural landscapes } \\
\text { - Cope with new challenges } \\
\text { (climate change, water } \\
\text { management, biodiversity, } \\
\text { renewable energies) }\end{array}$ & $\begin{array}{l}\text { - Rural development: climate change } \\
\text { adaptation, renewable energies }\end{array}$ & $\begin{array}{l}\text { - Water consumption } \\
\text { - Crop distribution }\end{array}$ \\
\hline & & & & & - Public expenditure \\
\hline \multirow[t]{9}{*}{ Water policies } & $\begin{array}{l}\text { WAP (Water Abstraction } \\
\text { Plan) } 1991 \text { onwards }\end{array}$ & Spain & $\begin{array}{l}\text { - Reduce agricultural water } \\
\text { consumption }\end{array}$ & - Water quotas & - Farm income \\
\hline & & & - Aquifer recharge & - No compensation of income loss & - Water consumption \\
\hline & & & - Wetland recovery & - Compulsory & $\begin{array}{l}\text { - Crop distribution } \\
\text { - Groundwater storage } \\
\text { - Public expenditure }\end{array}$ \\
\hline & $\begin{array}{l}\text { WFD (Water Framework } \\
\text { Directive) } 2000-2027\end{array}$ & $\begin{array}{l}\text { European } \\
\text { Union }\end{array}$ & $\begin{array}{l}\text { - Good ecological status of } \\
\text { water bodies } \\
\text { - Sustainable water use }\end{array}$ & $\begin{array}{l}\text { - Water pricing and application of } \\
\text { the 'Polluter Pays Principle' } \\
\text { - River Basin Management Plans - } \\
\text { Programs of measures }\end{array}$ & $\begin{array}{l}\text { - Groundwater level } \\
\text { (aquifer recharge) } \\
\text { - Cost-effectiveness of } \\
\text { different water } \\
\text { management strategies }\end{array}$ \\
\hline & & & $\begin{array}{l}\text { - Integrated water management } \\
\text { - Cost recovery } \\
\text { - Transparency and public participation }\end{array}$ & & \\
\hline & $\begin{array}{l}\text { SPUG (Special Plan for } \\
\text { the Upper Guadiana) } \\
2007-2027\end{array}$ & Spain & $\begin{array}{l}\text { - Good ecological status of } \\
\text { aquifers and associated } \\
\text { wetlands of the } \\
\text { Upper Guadiana basin }\end{array}$ & - Purchase of water rights & - Regional income \\
\hline & & & - Regional economic stability & - Legalization of illegal wells & $\begin{array}{l}\text { - Farmers' willingness } \\
\text { to sell water rights }\end{array}$ \\
\hline & & & $\begin{array}{l}\text { - Recover } 272 \mathrm{Mm}^{3} \text { by } 2027 \\
\text { in the 'Western La Mancha' } \\
\text { aquifer }\end{array}$ & $\begin{array}{l}\text { - Reforestation plans } \\
\text { - Water management and } \\
\text { control measures }\end{array}$ & $\begin{array}{l}\text { - Crop distribution } \\
\text { - Groundwater storage }\end{array}$ \\
\hline & & & & - Agricultural measures & - Cost-effectiveness \\
\hline
\end{tabular}

\footnotetext{
${ }^{a}$ Common Agricultural Policy.Source: Own elaboration based on Varela-Ortega (in press).
} 
and water policies in the area has frequently resulted in incoherent and disruptive outcomes, with concomitant social unrest in the rural communities, as it has been already explained in Section 1. Therefore, effective integration of agriculture policies and water policies is key for achieving the water management requirements of the EU WFD, as well as the CAP new provisions of environmental protection. One of the ways to approach this dual policy challenge is the integration of the economic and water domains into a common modeling platform that will allow capturing the overall complexity of the economic, social and environmental interactions in the area of study. This constitutes the novelty of this research and has been done by means of an integrated hydro-economic model, which represents a stylized mathematical replica of the social and water systems in the Western La Mancha aquifer.

Integrated hydro-economic models aim at capturing the diverse relations between the environment and the economy under water supply, climate and market uncertainties to better address climate-related hydrological questions as well as economic and social issues in complex water systems (Brouwer and Hofkes, 2008). The integration of hydrologic and economic models offer a more comprehensive vision about the economic and social consequences of water management for households, farms, and business firms and it constitutes a useful instrument to inform policy-makers and water managers on how to optimize the use of economic and water resources (De Fraiture, 2007). In hydroeconomic models, water may be re-allocated to high-value uses (based on the economic value it generates), increasing water efficiency and maximizing the value that water provides for society (Jenkins et al., 2004; Harou et al., 2009).

These innovative integrated tools improve decision making by providing relevant insights in terms of integrated water resources management and planning, water allocation, and institutional and financial design (Brouwer and Hofkes, 2008). Furthermore, when developed conjointly with the stakeholders, hydro-economic models may also promote a shared understanding of water resources systems and problems and offers a basis for negotiated policy solutions reducing water conflicts (Heinz et al., 2007).

Limitations of hydro-economic models have been extensively discussed by McKinney et al. (1999), Pulido-Velázquez et al. (2008), Maneta et al. (2009), and Harou et al. (2009), among others, who identify a number of methodological challenges mostly related with the models' resolution technique (simulation versus optimization) and the different spatial and time scales of the hydrologic and economic models. Generally, hydrologic models are bounded by geographical borders and refer to days or climatic seasons, while economic models are, in many cases, delimited by administrative boundaries and use longer time horizons based on annual time periods.

However, in spite of these limitations, integrated hydroeconomic modeling platforms have been widely and successfully used to address global water and food policy questions (Rosegrant et al., 2002; De Fraiture et al., 2003; De Fraiture, 2007) and to tackle complex multi-level water management issues in a number of basin locations worldwide (Lanini et al., 2004, in France; Jenkins et al., 2004, in US-California; Mainuddin et al., 2007, in Australia; Guan and Hubacek, 2008, in North China; Ahrends et al., 2008, in West Africa; Maneta et al., 2009, in Brazil). Following this trend, hydro-economic models have also been applied in Spain to address the complexity and multi-facet management endeavors in water-scarce basins that have to comply with the UE WFD (Andreu et al., 2006; Heinz et al., 2007; Pulido-Velázquez et al., 2008).

In this context, the objective of this research is to develop an integrated economic and hydrology modeling structure to explore a series of policy-based options for balancing the maintenance of rural livelihoods and the protection of groundwater systems in the area of the Western La Mancha aquifer. It considers the adaptive response of the social and ecological systems that face uncertain and changing water and climate regimes. Based on the integrated economic and hydrology perspective, the paper analyzes, specifically, the socio-economic and environmental effects of agricultural policies and water policies applied in the aquifer's region under different climate conditions. The research focuses, firstly, on a short-term analysis of the agricultural and water policies currently in force in the district, both at farm and basin levels. Secondly, in a long-term perspective, the paper analyzes the effects of future policies and climate scenarios along the time span set by the RBA to accomplish the recovery of the aquifer required by the WFD provisions.

\section{Methodological framework: Modeling integration}

The methodology developed to undertake this analysis is represented schematically in Fig. 3 and intends to replicate the complexity of the dynamic behavior of the social and ecological systems by integrating an economic and a hydrology model into a common platform. It comprises three main parts: (1) Baseline analysis supported by a statistical analysis, an ample farm-based field work (Varela-Ortega et al., 2006a), and a stakeholder consultation carried out from 2005 to 2007 and further complemented in 2008 within the framework of the EU project NeWater ${ }^{4}$ (Varela-Ortega et al., 2008). (2) Development of the modeling platform that consists in two types of models. A farmbased economic model (mathematical programming model, MPM) that simulates farmers' behavior when confronted with different agricultural and water policy scenarios. A hydrology model, (WEAP) (Water Evaluation And Planning system) that permits the up-scaling of the farm-based results on water consumption obtained in the economic model to the basin level and as such, allows assessment of the impacts of the different policies on the aquifer's recharge. (3) Integration of the hydrology and economic models toward analyzing the short-term and long-term climate and water policy scenarios.

\subsection{The baseline analysis}

For the baseline analysis and for modeling purposes, we have selected four statistically-based representative farms supported by an ample field work. These farms characterize the variety of production systems and farms types in the region in terms of area, percentage of irrigated land, water use, soil type, and crop distribution (see Table 2). These representative farms correspond to the Irrigation Community of Daimiel that covers around 20,000 ha of irrigated lands and has 1450 affiliated members. Situated in the western part of the La Mancha aquifer region, the municipality of Daimiel gives its name also to the nearby wetlands of the National Park 'Tablas de Daimiel'.

Statistical information for the baseline analysis was mainly obtained from government sources (regional and national), the River Basin Authority, and literature review. Additional data were collected from on-field farm surveys conducted in the main Irrigation Communities of the Western La Mancha aquifer and from direct consultation to the different stakeholder groups involved in water management issues (farmers, irrigation community representatives, technical experts, river basin managers, regional government officials, nature conservation groups, farmers unions) (Varela-Ortega et al., 2006a; Varela-Ortega et al., 2008). All information was compiled into a database. The baseline analysis

\footnotetext{
4 'New Approaches to Adaptive Water Management under Uncertainty', FP62003-GOCE-511179-2, DG Research, European Commission (2005-2009).
} 


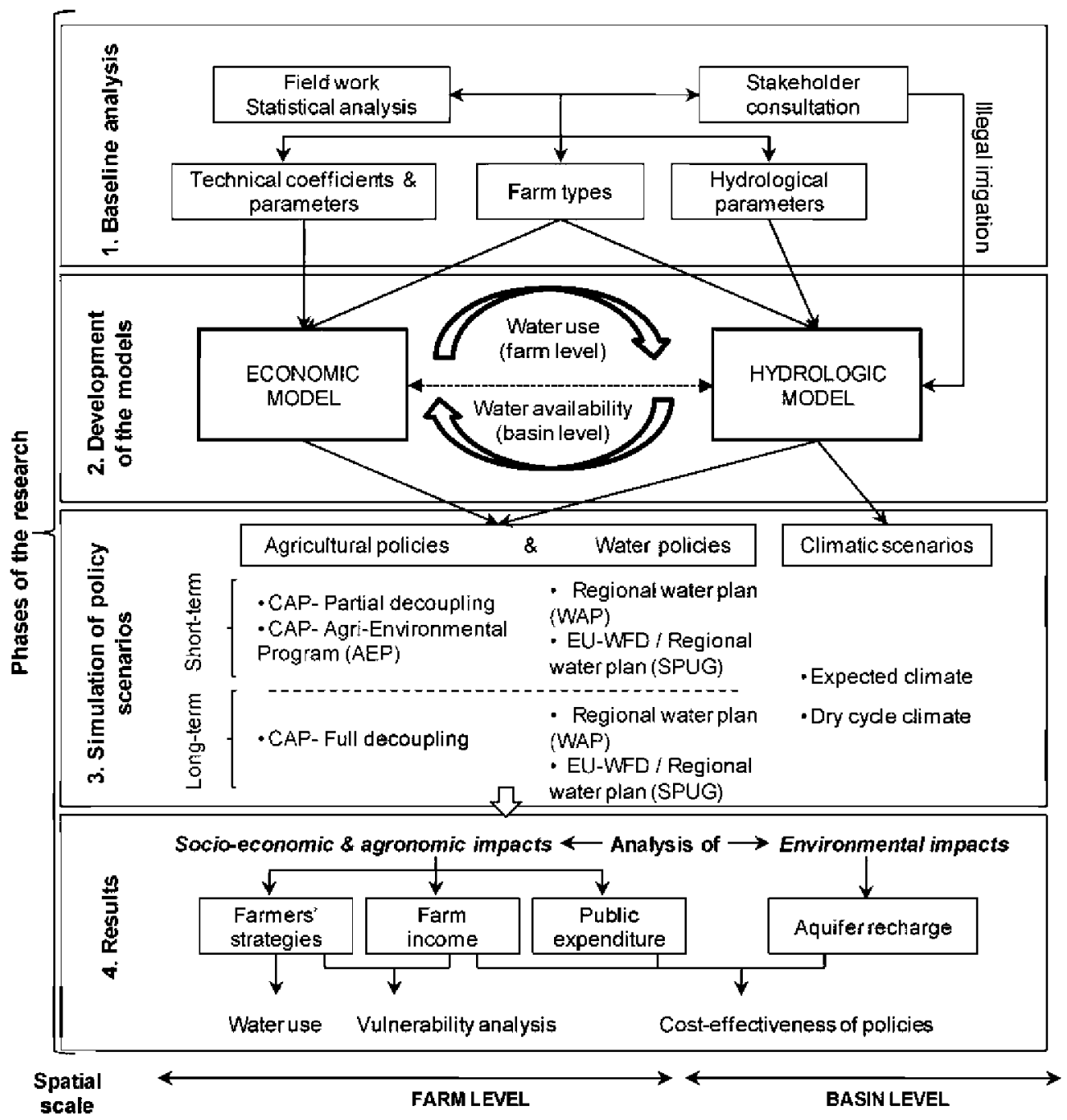

Notes: CAP (Common Agricultural Policy); EU-WFD (European Union- Water Framework Directive).

Fig. 3. Methodological scheme.

enables to determine the socioeconomic and biophysical characterization of the study area and to select the representative farms. It permits also to obtain the technical coefficients of the economic model (such as yields, crop prices, subsidies, crop water requirements, water costs, labor needs, labor costs, and crop production costs) and the hydrologic model (like water use and reuse rate, water losses, water diversions, water inflows and outflows, streamflow data, supply preferences and demand priorities, climatic variables, evaporation, natural recharge, and storage capacity of aquifers and reservoirs).

\subsection{The modeling platform}

\subsubsection{The economic model}

The economic model is a farm-based non-linear single-period mathematical programming model (MPM) of constrained optimi-

Table 2

Farm typology for the Irrigation Community of Daimiel in the region of Castilla-La Mancha.

\begin{tabular}{|c|c|c|c|c|}
\hline Index & F-1 & $\mathrm{F}-2$ & $\mathrm{~F}-3$ & $\mathrm{~F}-4$ \\
\hline Area (ha) & 8 & 24 & 30 & 70 \\
\hline Representativeness on the aquifer (\% of area) & 22 & 19 & 28 & 31 \\
\hline Soil quality & Low & High & Medium & Medium and low \\
\hline Cropping pattern & Vine $(100 \%)$ & $\begin{array}{l}\text { Winter Cereals (30\%) } \\
\text { Maize }(5 \%) \\
\text { Horticulture }(50 \%) \\
\text { Set-aside }(15 \%)\end{array}$ & $\begin{array}{l}\text { Winter Cereals (25\%) } \\
\text { Maize }(5 \%) \\
\text { Horticulture }(30 \%) \\
\text { Vine }(30 \%) \\
\text { Set-Aside }(10 \%)\end{array}$ & $\begin{array}{l}\text { Winter Cereals (58\%) } \\
\text { Maize (2\%) } \\
\text { Horticulture (30\%) } \\
\text { Set-Aside }(10 \%)\end{array}$ \\
\hline Historical water rights ( $\left.m^{3} / h a\right)$ & 2000 & 4278 & 4278 & 4278 \\
\hline Crop water requirements in the farms $\left(\mathrm{m}^{3} / \mathrm{ha}\right)$ & 2000 & 4498 & 3358 & 3686 \\
\hline Water Abstraction Plan (water quotas) $\left(\mathrm{m}^{3} / \mathrm{ha}\right)$ & 1000 & 2640 & 2640 & 2274 \\
\hline
\end{tabular}

Source: JCC-LM (2006) and field work from Varela-Ortega et al. (2006a). 
zation that maximizes a utility function (U) subject to technical, economic and policy constraints. This type of model, based on the principles of the micro-economic theory, has been widely used in the literature to characterize farmers' behavior and to analyze the foreseeable socio-economic and environmental effects of agricultural policies and water policies in a given regional context (Mejías et al., 2004; Gómez-Limón and Riesgo, 2004; Bartolini et al., 2007; Seeman et al., 2007; Varela-Ortega et al., 2006c; Varela-Ortega, 2007; Blanco-Gutiérrez et al., 2010; among others). The model here specified ads more complexity and scope to the water, agricultural and institutional parameters (such as water costs, soil types, irrigation techniques, crop production systems, cropping season, type of labor use), providing a more consistent and coherent representation of agricultural groundwater systems, usually unknown and rarely studied under a comprehensive modeling framework. It can be summarized as follows:

Objective function: based on the mean-standard deviation analysis following Hazell and Norton (1986),

\section{$\operatorname{Max} U=Z-\phi \cdot \sigma$}

where $U$ is the expected utility; $Z$ is the average net income; $\phi$ is the risk aversion coefficient and $\sigma$ is the standard deviation of the income distribution. Average farm income is calculated as follows:

$$
\begin{aligned}
Z= & \sum_{c} \sum_{k} \sum_{r} \operatorname{gm}_{c, k, r} \cdot X_{c, k, r} \\
& +\left[\sum_{c} \sum_{k} \sum_{r} \mathrm{subs}_{c, r} \cdot X_{c, k, r} \cdot \operatorname{coup}+\mathrm{sfp}\right] \cdot \text { mdu }-\mathrm{foc} \cdot \sum_{p} \mathrm{fla}_{p} \\
& -\mathrm{hlp} \cdot \sum_{p} \mathrm{hl} \mathrm{l}_{p}-\mathrm{wpc} \cdot \mathrm{wc}-\text { canon } \cdot \operatorname{sirrg}-\text { nwell } \cdot \text { twell }
\end{aligned}
$$

where $X_{c, k, r}$ are the decision-making variables representing the growing area by crop type $(c)$, soil type $(k)$, and irrigation technique $(r)$; $\operatorname{gm}_{c, k, r}$ : gross margin; subs ${ }_{c, r}$ : CAP support; coup: CAP coupling rate; spf: CAP single farm payment; mdu: CAP modulation rate; foc: family labor opportunity cost; fla $a_{p}$ : family labor availability; hlp: hired labor wage; $\mathrm{hl}_{\mathrm{p}}$ : hired labor; wpc: water pumping costs; wc: water consumption; canon: rate paid to the Irrigation Community; sirrg: irrigated surface; nwell: number of registered wells; twell: tax paid by well.

The standard deviation is defined by climate variability (crop yields) and market variability (crop prices) as follows:

$\sigma=\left[\frac{\left(\sum_{\mathrm{sn}} \sum_{\mathrm{sm}} Z_{\mathrm{sn}, \mathrm{sm}}-Z\right)^{2}}{N}\right]^{1 / 2}$

where $Z_{\mathrm{sn}, \mathrm{sm}}$ : random income as a function of the state of market prices $(\mathrm{sm})$ and of the state of nature $(\mathrm{sn}) ; N$ : combination of the different states $(N=100)$.

Land constraints: the growing area $\left(X_{c, k, r}\right)$ cannot exceed the amount of land available for each soil type $\left(\operatorname{surf}_{k}\right)$ and the total surface under irrigation (sirrig).

$\sum_{c} \sum_{k} \sum_{r} X_{c, k, r} \leq \operatorname{surf}_{k} \quad \sum_{c} \sum_{k} \sum_{r i} X_{c, k, r} \leq \operatorname{sirrg}$

Labor constraints: the crop labor requirements $\left(\mathbf{l r}_{c, r, p}\right)$ have to be covered by the availability of family labor (fla $a_{p}$ ) and hired labor on the market in each period $\left(\mathrm{hl}_{p}\right)$.

$\sum_{c} \sum_{k} \sum_{r} \operatorname{lr}_{c, r, p} \cdot X_{c, k, r} \leq \mathrm{fla}_{p}+\mathrm{hl}_{p}$
Water availability constraints: the crop water requirements ( wneed $_{c, k}$ ) have to be met by the water allotments granted by the basin authority (wava-sirrg), taking into account the technical efficiency of the on-farm irrigation systems $\left(h_{r}\right)$.

$\sum_{c} \sum_{k} \sum_{r}$ wneed $_{c, k} \cdot X_{c, k, r} \leq$ wava $\cdot \operatorname{sirrg} \cdot h_{r}$

Other policy relevant constraints related with the CAP: cropping permits; set aside requirements; etc.

The problem-solving instrument used is the General Algebraic Modeling System (GAMS).

The technical coefficients and parameters of the model were obtained from the field work and stakeholder consultation as explained in Section 3.1. The model was duly calibrated and validated, using the risk aversion coefficient $(\phi)$ as a calibration parameter and the comparative data on crop distribution, land and labor parameters in the study area.

\subsubsection{The hydrology model}

To quantify the impacts to aquifer storage in the basin under the different agricultural and water policies described above, the scenario-driven water resources modeling platform WEAP (Water Evaluation And Planning system) (SEI, 2008) was implemented. The WEAP modeling platform allows integration of pertinent demand and supply-based information together with hydrologic simulation capabilities to facilitate an integrative analysis of a user-defined range of issues and uncertainties, including those related to climate, watershed conditions, anticipated demand, ecosystem needs, regulatory drivers, operational objectives, and infrastructure. The user-defined demand structure and water allocation priority and supply preference designations drive the linear programming allocation algorithm for the water balance, allowing robust analysis of water allocation 'trade-offs' within possible future hydrologic and ecologic regimes developed in a scenario framework (Sieber and Purkey, 2007). WEAP permits to create and display a set of selected scenarios, defined in terms of water parameters, which were the same defined for the economic model. The use of WEAP and its user-friendly interfaces makes it particularly useful as a multi-scale water management tool and its robustness has been proven in a variety of worldwide applications (Purkey et al., 1998; Lévite et al., 2003; Yates et al., 2005; Purkey et al., 2007; Assaf and Saadeh, 2008). The WEAP model has been specified, calibrated and validated for the Upper Guadiana basin. Following previous work by the authors (Varela-Ortega et al., 2006b; Varela-Ortega et al., 2009), a representation of the basin, including all pertinent demand and supply elements and their inter-relations, was constructed in WEAP using its graphical user interface (see Fig. 4). The new modeling includes the long term analysis, climate variations and the specific issues of the regional water plan (SPUG), such as the purchase of water rights and the legalization of illegal wells.

Elements include major rivers (blue lines), major aquifers (green squares), and most important water demand nodes (red circles). Water demand nodes comprise one environmental water demand ('Tablas de Daimiel' wetland), two domestic urban water demands (D.A_1 and D.A_2), and nine agricultural water demands. Seven of the nine agricultural demand nodes and one of the urban domestic nodes (D.A_2) derive irrigation water from groundwater (UH_04.04, that is, the Western La Mancha aquifer); one agricultural demand node (Agri-Penarroya) and one urban domestic node (D.A_1) derive irrigation water from a local reservoir (green triangle) on the Upper Guadiana river. Green arrows represent transmission links between demand nodes and their preferred water supply sources. Demand nodes return 


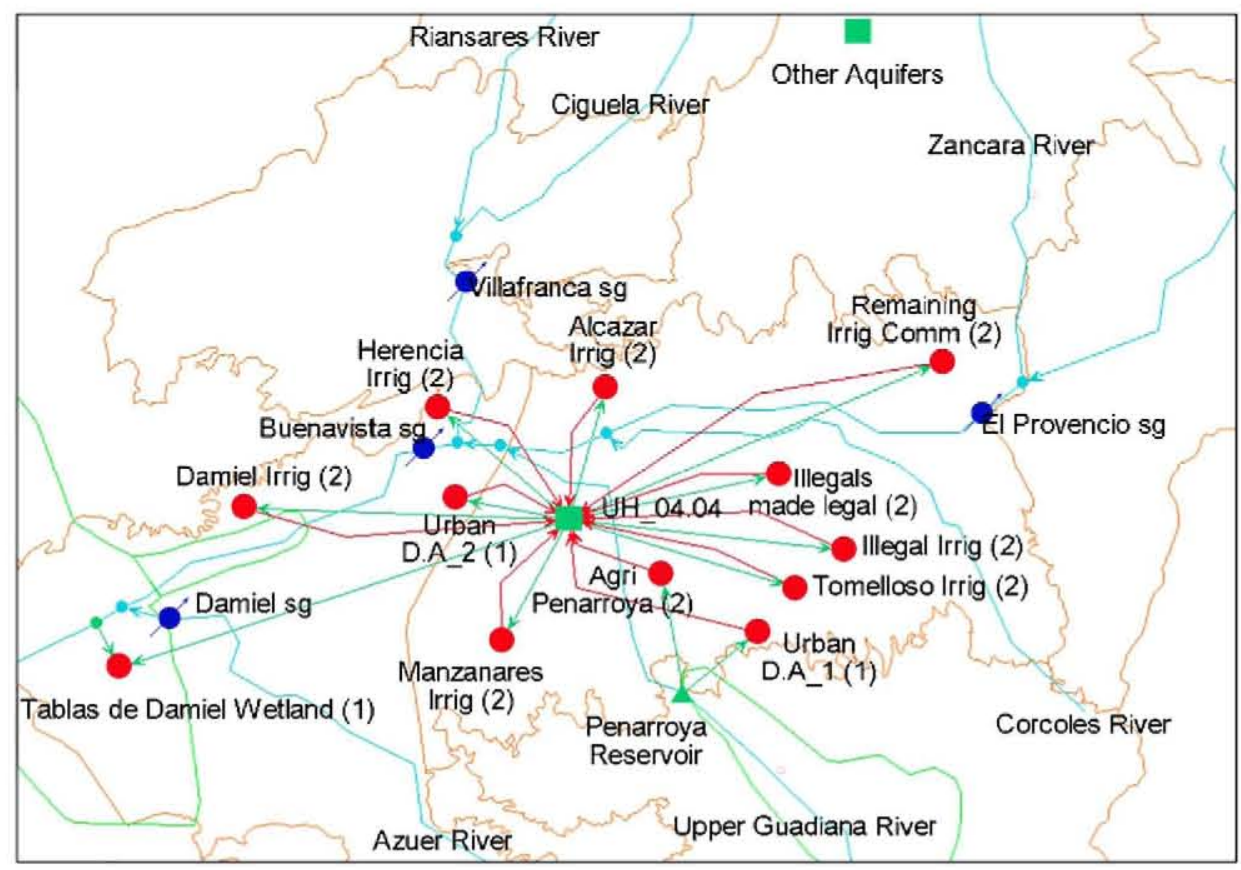

Fig. 4. WEAP layout of the Upper Guadiana basin.

unconsumed water to groundwater (infiltration; via red arrow links) in this construct, behind each model elements lies the associated user-defined data that drives the water balance calculations, such as population, agricultural area, water use rates, groundwater recharge, streamflow, and reservoir capacity.

On the supply side, streamflow and groundwater recharge for the starting year of the analysis (2002) were derived from existing data and estimates. For river headflow, the mean value of monthly headflow over the period 1946-1997 was used, and for groundwater recharge, an estimate of current recharge (comprising contributions from rainfall, riverbed infiltration, agricultural and domestic runoff infiltration, and lateral inflows/outflows) was obtained from the Guadiana River Basin Authority.

\subsection{Modeling integration and scenario simulation}

Integration of the economic and hydrology models is done by means of mapping the selected farm types on the specific geographical sites of the Irrigation Communities located in the aquifer boundaries and by simulating the same policy scenarios in both models.

In the economic model, different policy scenarios were selected with the purpose of analyzing the response of different farmers to diverse agricultural policies and water policies in a short-term (2006-2009) and long-term (2010-2027) time horizon. All the scenarios simulated correspond to public policies defined by the EU and national public authorities (see Table 1). The time horizon is defined by the period during which public policies are in force. The short-term period (2006-2009) covers the period of time from the baseline situation (2006) up to the end of the CAP Luxembourg reform (2009). The long-term period (2010-2027) is delimited by the starting year of the CAP-'Health Check' reform (2010) and the deadline established by the WFD for achieving environmental goals (2027).

1. Short term policy scenarios (2006-2009): The CAP-Luxembourg reform is the baseline situation represented by CAP direct payments partially decoupled from production (i.e. $25 \%$ of these payments are still linked to agricultural production levels). This baseline CAP scenario has been simultaneously simulated with different water policy options:

- Reference water policy (before the establishment of the WAP): farmers receive their full water allotments (historical water rights, $4278 \mathrm{~m}^{3} /$ ha).

- WAP (Water Abstraction Plan): different levels of water quotas are established for water consumption dependent on farm size $\left(0-30 \mathrm{ha}=2640 \mathrm{~m}^{3} / \mathrm{ha} ; \quad 30-80 \mathrm{ha}=2000 \mathrm{~m}^{3} / \mathrm{ha}\right.$; $>80 \mathrm{ha}=1200 \mathrm{~m}^{3} / \mathrm{ha}$; vineyard $=1000 \mathrm{~m}^{3} / \mathrm{ha}$ ).

- AEP (Agri-Environmental Program): 50\% and 100\% reduction of the assigned WAP water quotas and a compensation payment according to farm size. Compensation payments when water consumption is reduced by $50 \%$ are: 1 40 ha $=209 € /$ ha; $40-80$ ha $=125 € /$ ha; $>80$ ha $=63 € /$ ha. If water use is reduced by $100 \%$ (rainfed agriculture), the payments are: $1-40 \mathrm{ha}=518 € /$ ha; $40-80 \mathrm{ha}=311 € /$ ha; $>80$ ha $=155 € /$ ha.

- SPUG (Special Plan for the Upper Guadiana): it is defined by the purchase of water rights (PWR) by the RBA for three levels of prices paid to the farmers, $3000 € /$ ha $\left(P_{1}\right), 6000 € /$ ha $\left(P_{2}\right)$, and $10,000 € /$ ha $\left(P_{3}\right)$. The farmers selling their water rights do it on a permanent basis and turn to rainfed farming.

2. Long term policy scenarios (2010-2027). In the long term, the new CAP-Health Check reform is defined by CAP direct payments fully decoupled from agricultural production levels. It has been simultaneously simulated with the reference water policy, the WAP, and the SPUG. The AEP program is not considered in the long-term analysis because it finalized in 2006 (see Table 1 and Fig. 2).

All these specified policy scenarios have also been simulated in the hydrology model, which provides the formal framework for a dynamic policy analysis. Time dependencies of variables or other relational dependencies between variables are defined in the hydrology model. For example, in this study, the SPUG's measures for reducing water abstractions (purchase of water rights, closing up unlicensed wells, reforestation and rainfed farming programs, 
see Table 1) are manifested in the hydrology through reductions in the area of each regional agricultural demand node with time, till recover the 272 million $\mathrm{m}^{3}$ stipulated in the SPUG (CHG, 2007a). Furthermore, we have simulated the SPUG measure related with the legalization of illegal wells ( see Table 1), that consists of using a portion of the purchased water rights (specifically, 32 million $\mathrm{m}^{3}$ ) to 'convert' illegal farmers to legal status. As such, we have added the additional agricultural demand node ('Illegals made Legal'; Fig. 4) that becomes active in the scenario year 2007, and which grows in area during the period 2007-2009 to accommodate the water rights granted.

Additionally, different future climate scenarios have been simulated using the hydrology model. Future expectations for groundwater recharge and streamflow are important variables to consider in this analysis of the ability of certain agricultural policies to mitigate groundwater decline in the basin. While output derived from any type of climate model can be input directly into WEAP to represent expected future hydrologic conditions, this study chose to represent future climate conditions with a simpler construct. For future climate conditions, we derived two sequences. For the first climate sequence ('expected climate'), year 2000 streamflow and the portion of groundwater recharge due to precipitation, lateral inflows/outflows, and riverbed infiltration were each decreased by $0.45 \%$ annually to represent $11 \%$ cumulative decrease in water availability expected by 2027 according to the future climate change projections of the Spanish Office of Climate Change (Moreno, 2005; CHG, 2007a). For the second climate sequence ('dry cycle climate'), we analyzed the river headflow dataset (1946-1997) to obtain 90th, 75th, 25th, and 10 th percentile values and normalized them by the mean (50th percentile) value. The resulting factors were used to define very dry (normalized 10th percentile equal to 0.1 ), dry (normalized 25th percentile equal to 0.3 ), wet (normalized 75 th percentile equal to 2.5) and very wet (normalized 90th percentile equal to 5.1) conditions relative to normal (50th percentile equal to mean value). These factors could then be applied to the starting year
(2000) river headflow and groundwater recharge to generate a simple future climatic sequence with interannual variability. In the last century, the Guadiana basin has experienced several droughts characterized by three years of consecutive dry spell (CHG, 2007b). According to that, we used an alternating three year 'dry' and two year 'normal' sequence as the second climate expectation to simulate the impact of periodic drought conditions.

The farm-based results of the economic model (cultivated area and annual water use rate) were entered into the demand nodes of the WEAP model, permitting the up-scaling to the basin's level of all water parameters resulting from the policy simulations. It was then possible to assess the aquifer's water storage for different climate scenarios and hence its recharge capacity in each of the short-term and long-term policy scenarios. The model results allow us to show how these farms will be able to comply with the WFD requirements along the established time horizon of 2027.

\section{Results and discussion}

The simulation results of the economic model are summarized in Tables 3 and 4 below, aggregating the farm-level results with the correspondent farm-size weighs and showing, respectively, the short term and the long term analyses. As explained in Section 3.3, in the short term analysis the CAP scenario corresponds to the partial decoupling scheme (PD) prevalent in Spain up to 2009. For the long term analysis, the CAP programs entail a full decoupling structure (FD). Water policies have been analyzed for both types of agricultural policy settings selecting the current programs in force in each period.

\subsection{The agronomy: Water consumption and cropping patterns}

Results from the economic model show that in the short term partial decoupling scenario, water use reductions to reach the aquifer's recharge target are met for the WAP and the AEP programs (from over $3300 \mathrm{~m}^{3} /$ ha in the reference situation to

Table 3

Aggregated results of policy analysis in the Partial Decoupling scenario (PD) (short term, representative year for the period 2006-2009).

\begin{tabular}{|c|c|c|c|c|c|c|c|}
\hline \multirow[t]{3}{*}{ Aggregate results } & \multicolumn{7}{|l|}{ Policy option } \\
\hline & \multirow[t]{2}{*}{ Ref. water policy } & \multirow[t]{2}{*}{ WAP $^{a}$} & \multicolumn{2}{|l|}{$\mathrm{AEP}^{\mathrm{b}}$} & \multicolumn{3}{|l|}{ SPUG-PWR ${ }^{c}$} \\
\hline & & & $\mathrm{AEP}_{1}=50 \%$ Red & $\mathrm{AEP}_{2}=100 \%$ Red. & $P_{1}=3000 € / h a$ & $P_{2}=6000 € / h a$ & $P_{3}=10,000 € / h a$ \\
\hline \multicolumn{8}{|l|}{ Farm income } \\
\hline Total $(€ /$ ha $)$ & 917 & 769 & 769 & 691 & 421 & 641 & 936 \\
\hline$\%$ of ref. policy & 100 & 84 & 84 & 75 & 46 & 70 & 102 \\
\hline \multicolumn{8}{|c|}{ Water Consumption } \\
\hline Total $\left(\mathrm{m}_{3} / \mathrm{ha}\right)$ & 3304 & 2495 & 1247 & 0 & 0 & 0 & 0 \\
\hline$\%$ of ref. policy & 100 & 75 & 38 & 0 & 0 & 0 & 0 \\
\hline \multicolumn{8}{|l|}{ Public Expenditure } \\
\hline Total (€/ha) & 127 & 130 & 328 & 612 & 343 & 563 & 858 \\
\hline$\%$ of ref. policy & 100 & 103 & 258 & 482 & 270 & 443 & 675 \\
\hline \multicolumn{7}{|c|}{ Water Shadow Price } & 0.973 \\
\hline \multicolumn{8}{|l|}{ Water costs } \\
\hline Total $\left(€ / \mathrm{m}^{3}\right)$ & 0.061 & 0.061 & 0.063 & 0 & 0 & 0 & 0 \\
\hline $\begin{array}{l}\text { Water Productivit } \\
\text { Total }\left(€ / \mathrm{m}^{3}\right)\end{array}$ & \multicolumn{3}{|c|}{ Water Productivity } & 0 & 0 & 0 & 0 \\
\hline \multicolumn{8}{|c|}{ Inc. compensation AEP } \\
\hline Total $\left(€ / \mathrm{m}^{3}\right)$ & - & - & 0.159 & 0.197 & - & - & - \\
\hline \multicolumn{8}{|l|}{ Crop distribution } \\
\hline Rainfed (\%) & 0 & 19 & 52 & 100 & 100 & 100 & 100 \\
\hline Irrigated (\%) & 100 & 81 & 48 & 0 & 0 & 0 & 0 \\
\hline
\end{tabular}

a Water Abstraction Plan.

b Agri-environmental Programs.

c Special Plan for the Upper Guadiana-Purchase of Water Rights. 
Table 4

Aggregated results of policy analysis in the Full Decoupling scenario (FD) (long term, representative year for the period 2010-2027).

\begin{tabular}{|c|c|c|c|c|c|}
\hline \multirow[t]{3}{*}{ Aggregate results } & \multicolumn{5}{|l|}{ Policy option } \\
\hline & \multirow[t]{2}{*}{ Ref. water policy } & \multirow[t]{2}{*}{$\mathrm{WAP}^{\mathrm{a}}$} & \multicolumn{3}{|l|}{ SPUG-PWR ${ }^{b}$} \\
\hline & & & $P_{1}=3000 € /$ ha & $P_{2}=6000 € / \mathrm{ha}$ & $P_{3}=10,000 € / \mathrm{ha}$ \\
\hline \multicolumn{6}{|l|}{ Farm income } \\
\hline Total (€/ha) & 958 & 921 & 434 & 655 & 949 \\
\hline$\%$ of ref. policy & 100 & 96 & 45 & 68 & 99 \\
\hline \multicolumn{6}{|l|}{ Water consumption } \\
\hline Total $\left(\mathrm{m}^{3} / \mathrm{ha}\right)$ & 3261 & 2495 & 0 & 0 & 0 \\
\hline$\%$ of ref. policy & 100 & 76 & 0 & 0 & 0 \\
\hline \multicolumn{6}{|l|}{ Public expenditure } \\
\hline Total (€/ha) & 130 & 130 & 343 & 563 & 858 \\
\hline$\%$ of ref. policy & 100 & 100 & 263 & 432 & 657 \\
\hline \multicolumn{6}{|c|}{ Water shadow price } \\
\hline Total $\left(€ / \mathrm{m}^{3}\right)$ & 0.004 & 0.067 & 0.973 & 0.973 & 0.973 \\
\hline \multicolumn{6}{|l|}{ Water costs } \\
\hline Total $\left(€ / \mathrm{m}^{3}\right)$ & 0.061 & 0.061 & 0 & 0 & 0 \\
\hline \multicolumn{6}{|l|}{ Water productivity } \\
\hline Total $\left(€ / \mathrm{m}^{3}\right)$ & 0.321 & 0.368 & 0 & 0 & 0 \\
\hline \multicolumn{6}{|l|}{ Crop distribution } \\
\hline Rainfed (\%) & 0 & 41 & 100 & 100 & 100 \\
\hline Irrigated (\%) & 100 & 59 & 0 & 0 & 0 \\
\hline
\end{tabular}

a Water Abstraction Plan.

b Special Plan for the Upper Guadiana-Purchase of Water Rights.

$2495 \mathrm{~m}^{3}$ /ha and $1247 \mathrm{~m}^{3} /$ ha respectively). This level is also attained in the long term analysis, although AEP programs disappear and in its place, the SPUG is applied for the three levels of water rates as established in the program (Tables 3 and 4). This result does not mean that the recharge target will be met in the overall sub-basin, as evidenced in the hydrology analysis (see Section 4.5).

In Fig. 5, we can see that farming extensification takes place when the WAP is enforced; that is, rainfed farming appears and intensive irrigation crops, such as maize, are sharply reduced in favor of less water demanding crops, such as winter cereals. Intensive vegetable production is also diminished. In the full decoupling scheme of the long term analysis, extensification starts even in the reference situation, and this trend is reinforced in the more water-scarce WAP, evidence of a clear synergy of CAP programs with water conservation targets. Along these lines, several studies show that the decoupling scheme favor the extensification of production systems (see e.g. Mejías et al., 2004; Bartolini et al., 2007; Oñate et al., 2007; Balkhausen et al., 2008).
Moreover, full decoupling shows a polarization of cropping trends. Intensively irrigated cereals are clearly penalized in the FD scenario. These crops, having higher yields, have lost the comparative advantage they profited in the previous CAP programs in which subsidies where dependent on crop yields. Then, they are substituted by horticulture crops, non supported by the CAP, and by rainfed crops.

\subsection{Farm income and purchase of water rights}

In the aggregate farm type (Tables 3 and 4 ), which represent the aggregation of all farm types based on their representativeness on the aquifer (\% of area) (see Table 2 ), farm income is reduced by $20 \%$ when the WAP quotas are applied in the short term partial decoupling scenario. This tendency is mitigated in the long term full decoupling scenario, suggesting that a full decoupled subsidy scheme acts as a risk shelter for irrigated farming. However, when farmers sell their water rights within the SPUG program, both scenarios produce equivalent farm income reductions, and the original level of income gain is only attained when water rights are
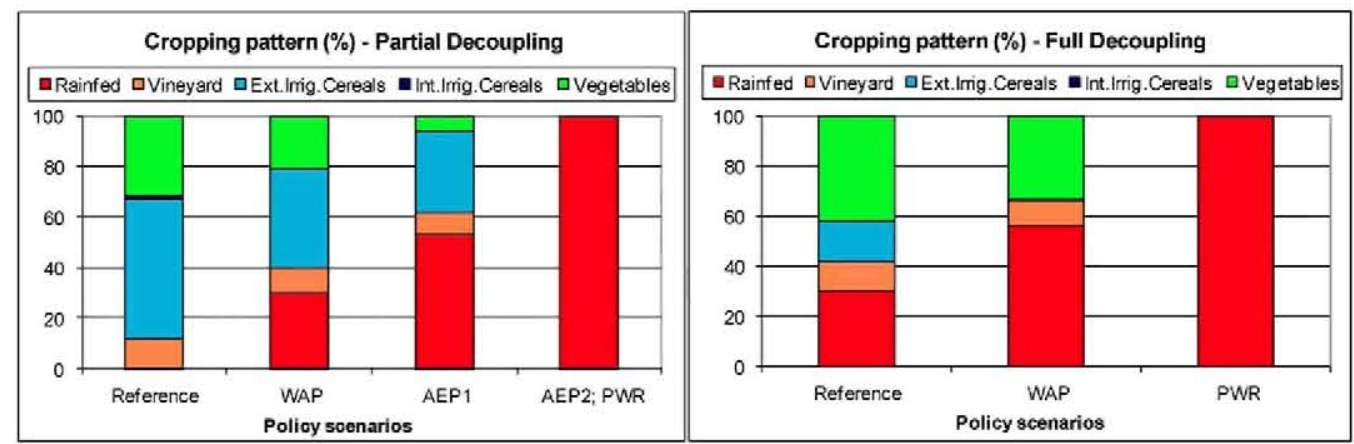

Notes: WAP (Water Abstraction Plan); AEP1 (Agro-Environmental Program, 50\% of water reduced); AEP2 (Agro-Environmental Program, 100\% of water reduced); PWR (Purchase of Water Rights of the Special Plan for the Upper Guadiana).

Fig. 5. Crop distribution by policy program in the Partial Decoupling and Full Decoupling scenarios. 

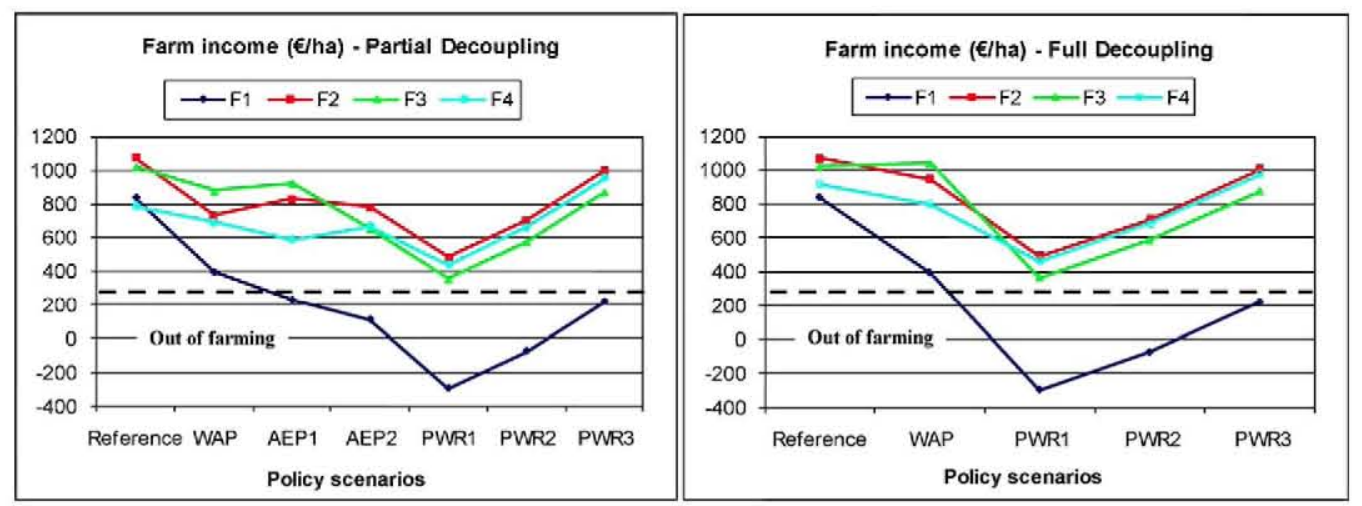

Notes: WAP (Water Abstraction Plan); AEP1 (Agro-Environmental Program, 50\% of water reduced); AEP2 (Agro-Environmental Program, 100\% of water reduced); PWR (Purchase of Water Rights of the Special Plan for the Upper Guadiana when the price of purchase is $\mathrm{P} 1=3000 € / \mathrm{ha}(\mathrm{PWR} 1), \mathrm{P} 2=6000 € /$ ha (PWR2), and P3= $10000 € /$ ha (PWR3)).

Fig. 6. Farm income variations by policy program and farm type in the Partial Decoupling and Full Decoupling scenarios.

compensated at the highest price rate of $10,000 € /$ ha. VarelaOrtega et al. (2006c) and Szvetlana et al. (2010) demonstrate that the effects of the CAP decoupling on farm income are generally slight.

When comparing the different types of farms (Fig. 6), results show that income is reduced less drastically as water availability diminishes across scenarios when subsidies are fully decoupled from production (FD scenario). Again, for all farms, the fully decoupled program is less risky for farming than the precedent production-based program.

However, willingness to sell the entitled water rights varies across farm types and irrigators' attitudes, and it is dependent on the cropping pattern chosen in each scenario. Prices offered by the RBA in the water rights exchange center range from 3000 to $10,000 € /$ ha for herbaceous annual crops and from 3000 to $6000 € /$ ha for permanent crops (vineyards). An irrigator will be willing to sell his water rights when the price perceived will compensate his lost income when passing from irrigation farming (in the WAP situation) to rainfed farming. As water rights are sold on a permanent basis, the total income loss will be calculated over a period of 20 years along which water rights will hold. Annual income loss, obtained in the model, is then taken as the annuity of the foregone income flow over the 20 year period (interest rate is set at a real rate of $4 \%$ ). Table 5 shows the willingness to sell for the different types of farms. We can see that only F2 and F4 farm types will be willing to sell their water rights if water prices reach the upper level. In both cases, total income loss will be compensated by the revenue perceived for selling their water rights. Similar studies on water banks and water markets in Spain (see e.g. Iglesias, 2001; Arriaza et al., 2002; Calatrava and Garrido, 2005; Albiac et al., 2006; Gómez-Limon et al., 2007; Blanco-Gutiérrez et al., 2010) demonstrate that farmers' willingness to sell water is higher in large and medium farms than in small farms.

\subsection{Farms' adaptive response}

The capacity that farms have to adapt to different levels of water scarcity can be analyzed by looking at the water shadow prices (dual values) in the model results (see Tables 3 and 4). Water shadow prices, which represent the marginal value of water, can be used to assess the impact of water conservation policies. Its usefulness has been discussed extensively in the literature, as average values for water can be ambiguous or misleading (Johansson et al., 2002; Turner et al., 2004; Hanemann, 2006; among others). The value of water for farmers is not constant and increases as less water is supplied because farmers are likely to change their crops and technologies in response to water availability. This is shown in the model results. Fig. 7 depicts the shadow prices of water for different levels of water availability obtained in the model simulations for the different farm types. The water availability levels that we have considered correspond to the policy options specified in Table $4\left(\mathrm{AEP}_{1}, \mathrm{AEP}_{2}\right.$, WAP, reference water policy) and the volume of water needed to obtain a water shadow price (WSP) equal to zero. When there is no water available, such as the case of rainfed farming, WSP is the highest. In contrast, when WSP is zero, the farm will be satisfied with the amount of water available to fulfill its crop-choice water requirements and, therefore, will not be willing to pay for an extra unit of water.

The 'water demand curves' constructed using water shadow prices show that farm types have distinctive adaptive response to water availability. Curves show the farms' ability to adjust their cropping patterns, technologies and farming operations. We can see that the diversified larger and medium-size farms, F4 and F3 respectively, are more adapted to water stress conditions as they change their annual crops more easily than less diversified farms. F4 can operate with $5500 \mathrm{~m}^{3} /$ ha without willing to pay for extra

Table 5

Farmers' simulated willingness to sell water rights in the short-term (Partial Decoupling scenario, 2006-2009) and long-term (Full Decoupling scenario, 2010-2027).

\begin{tabular}{|c|c|c|c|c|}
\hline \multirow[t]{2}{*}{ Representative farms type } & \multirow[t]{2}{*}{ Maximum compensation payment ( $€ /$ ha) } & \multirow{2}{*}{$\begin{array}{l}\text { Income loss of farmers for selling their water rights ( } € / \mathrm{ha} \text { ) } \\
\mathrm{PD}^{\mathrm{a}}\end{array}$} & \multicolumn{2}{|c|}{ Sale of water rights } \\
\hline & & & $\mathrm{FD}^{\mathrm{b}}$ & $(€ / \mathrm{ha})$ \\
\hline F1 & 6000 & 7154 & 7154 & No \\
\hline F2 & 10000 & 8545 & 12312 & YES (only in PD) \\
\hline F3 & 8800 & 13575 & 16353 & NO \\
\hline F4 & 10000 & 8614 & 10175 & YES (only in PD) \\
\hline
\end{tabular}

${ }^{a}$ Partial decoupling.

b Full decoupling. 

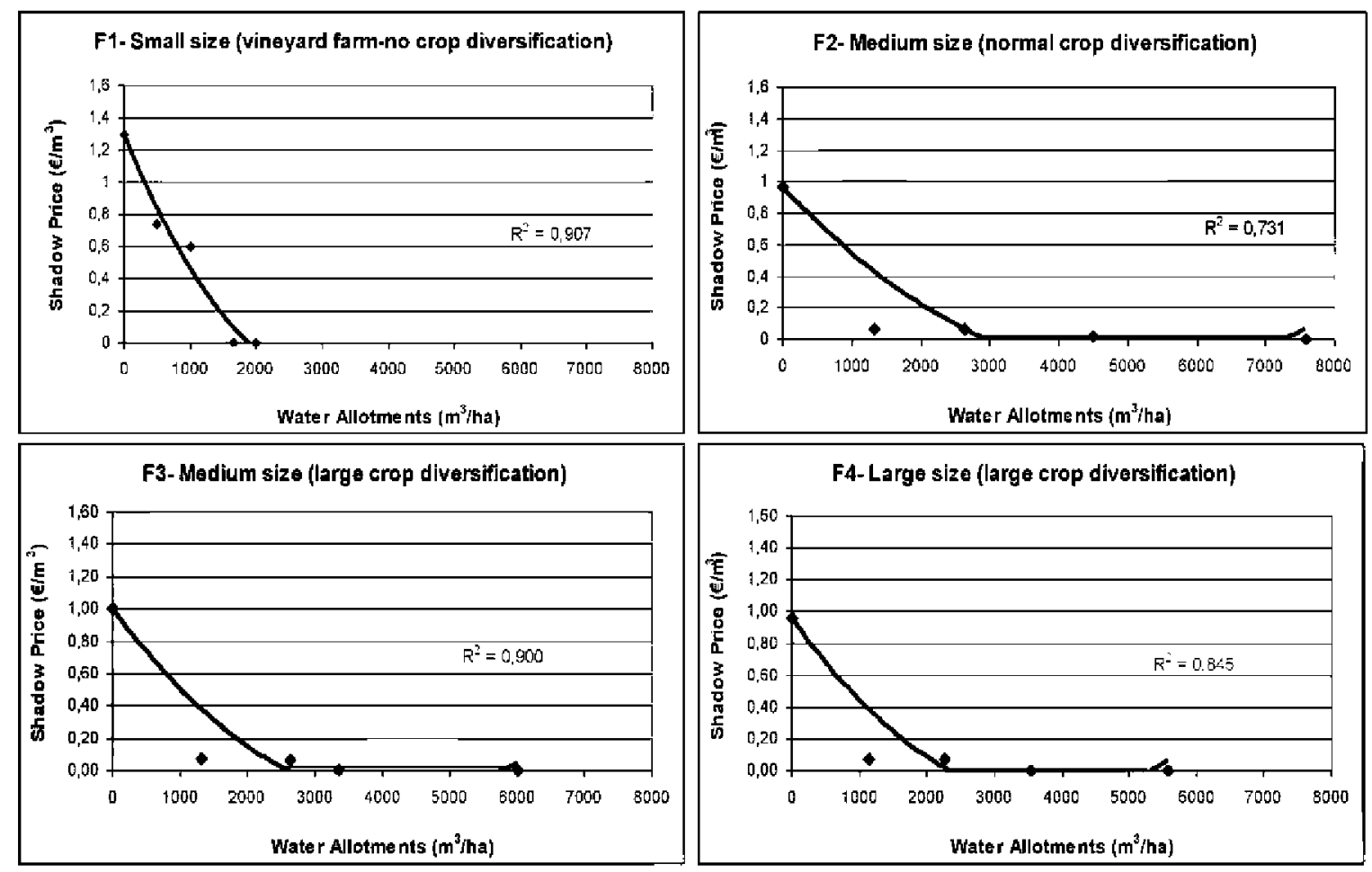

Fig. 7. Water shadow prices in the different farm types for different levels of water availability (Full Decoupling scenario).

units of water and, equivalently, F3 will be satisfied with $6000 \mathrm{~m}^{3} /$ ha. In contrast, its less diversified medium-size counterpart, F2, requires a larger volume of water $\left(7500 \mathrm{~m}^{3} / \mathrm{ha}\right)$ to meet its crop pattern and has a lower adaptation capacity. This difference can be explained by the fact that farm F3 has one third of its surface dedicated to vine cultivation that requires a lesser amount of water. Vine is cultivated with modern water-saving drip irrigation technologies that are very well adapted to the soils and climate conditions of the region.

In addition, looking at the water demand curves intersections with the $\mathrm{X}$ and $\mathrm{Y}$ axes, we can compare the water adjustment process of the medium size farms F2 and F3. F3 will continue to farm adjusting its crop mix with less water being available up to a minimum of $2500 \mathrm{~m}^{3} /$ ha without willing to pay for an extra unit of water (WSP equals zero). Thereafter, if less water is available, the farm will be willing to pay for extra units of water to continue farming (WSP being greater than zero up to $1 € / \mathrm{m}^{3}$ ). Equivalently, the F2 farm will tolerate less water reductions than F3. It will continue adjusting its crop pattern up to a minimum water volume of $3000 \mathrm{~m}^{3}$ / ha without having to pay for an extra unit of water. This result evidences that there are other factors, besides farm size and cropping diversity that explain the farms' ability to adjust to changing water availability. These are technology and crop adjustments to the region's agronomic conditions. In fact, the combination of irrigation technology and crop type also explains the high capacity to adapt to water stress shown by the numerous small vineyard farms in the area. In our study, the small vineyard farm F1 is highly adapted to lower water volumes and it satisfies its water requirements with about one third of the water required by the other farms $\left(2000 \mathrm{~m}^{3} / \mathrm{ha}\right)$ due to the use of efficient drip irrigation technologies that are widely used in vine groves in the region.

The higher adaptive response to water stress shown by the large F4 farm and the medium-size F3 farm is consistent with their income response as well. Both farms lose a smaller proportion of farm income under the WAP scenario and under the purchase of water rights scenario (PWR) (see Fig. 6) when compared to the other farm types. This result indicates that economies of scale, as well as cropping mix potential, play an important role in the adjustment process towards water scarcity in this region. In this regard, numerous studies (such as, Smit et al., 1996; Iglesias et al., 2000; Smit and Skinner, 2002; Iglesias and Quiroga, 2007; Challinor et al., 2007; Ahrends et al., 2008; Purkey et al., 2008; Maneta et al., 2009; among others) suggest that the diversity of farm sizes, cropping potential and intensive cultivation possibilities of the regions reduces vulnerability to climate variability and droughts. Hence, regional diversity can be a resource for climate adaptation strategies (Reidsma and Ewert, 2008).

\section{Public expenditure and cost-effectiveness}

The role of the Agri-environmental programs for conserving water resources is limited as these programs require large public funds. Compared with the reference baseline scenario, public expenditure is more than two-fold and four-fold greater, respectively, in the AEP $50 \%$ and $100 \%$ schemes $(258 \%$ and $482 \%$ ). Thus cost-effectiveness of these programs is low. Public expenditure is equivalent in the purchase of water rights program (SPUG) for the medium price range level, but water is reduced further in this program, especially in the long term perspective. Shown in Fig. 8 is the breakdown of public expenditure into CAP subsidies, compensation payments of the Agri-environmental programs (AEP), and purchase of water rights (PWR).

\subsection{Meeting environmental objectives: Aquifer recharge}

Impacts to groundwater storage through 2027 are demonstrated in the results of the WEAP simulations (Fig. 9). Under the first climate condition, in which streamflow and natural groundwater recharge decrease by $11 \%$ cumulatively over the period, groundwater storage would decrease by approximately 5 billion $\mathrm{m}^{3}$ beyond current levels if no corrective action were taken ('Refer- 


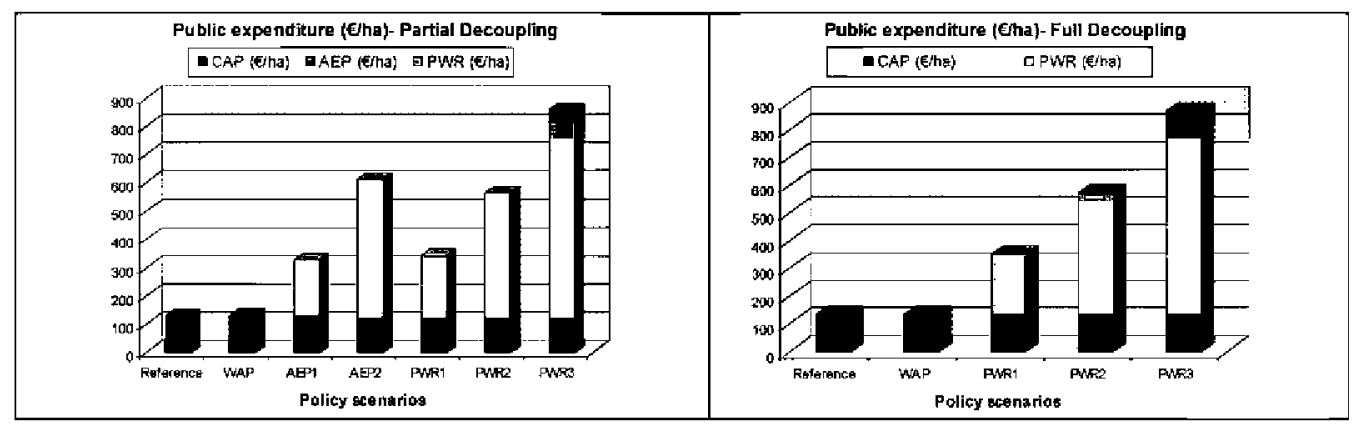

Notes: CAP (Common Agricultural Policy. subsidies): WAP (Water Abstraction Plan); AlP (AgroEnvironmental Program, payments); AEP1 (50\% of water reduced); AEP2 (100\% of water reduced); PWR (Purchase of Water Rights of the Special Plan for the Upper Guadiana when the price of purchase is $\mathrm{Pl}=3000$ E/ha (PWR1), P2=6000 E/ha (PWR2), and P3=10 0006/ha (PWR3)).

Fig. 8. Public expenditure (€/ha) by policy program in the Partial Decoupling and Full Decoupling scenarios.

ence' in Fig. 9), i.e., irrigators use water at rates existing before 2001. If only the WAP policy ('WAP only' in Fig. 9) had been implemented in 2001 and continued beyond 2006, storage would fall another 2.3 billion $\mathrm{m}^{3}$ by 2027 . In contrast, a 2.8 billion $\mathrm{m}^{3}$ increase in storage relative to the 2006 volume is anticipated if one assumes all farm types fully participate in SPUG policy conditions starting in 2007 following a period (2001-2006) in which only F2 farms opted to comply with AEP reductions (at 100\% reduction; 'F2 AEP to 2006 then SPUG; Fig. 9). If no farms agree to sell water rights under the SPUG policy implementation, groundwater storage roughly maintains its present volume, losing approximately 900 million $\mathrm{m}^{3}$ ('F2 AEP to 2006 then failed SPUG'; Fig. 9).

The situation could be much different if future climate is characterized by cyclic droughts, rather than the gradual decrease in rainfall, streamflow, and groundwater recharge represented by the 'expected' climate. Under the 'Dry Cycle' climate, even if all farm types participate fully in SPUG starting in 2007, groundwater storage is simulated to increase by only 76 million $\mathrm{m}^{3}$ relative to the 2006 volume ('F2 AEP to 2006 then SPUG, Dry Cycle climate;
Fig. 9). If the SPUG policy fails, with no farms selling water rights, aquifer storage decreases by 3.6 billion $\mathrm{m}^{3}$ through 2027-a situation worse than if only the WAP policy had been continued through 2027 under the 'expected' climate. Similar results have been obtained using WEAP in the Sacramento Valley in California, where climate projections indicate a strong increase in groundwater pumping to irrigate vegetable crops during drought periods. That study shows that prolonged drought triggers adaptation strategies among farmers, such as the use of more efficient irrigation technologies and cropping changes that favor rainfed farming (Purkey et al., 2008).

For those agriculture areas that depend on surface water for irrigation, specifically in the Peñarroya area of the basin where irrigation water is obtained from the Peñarroya reservoir on the Upper Guadiana River (see Fig. 4), the impact of the 'Dry Cycle' climate conditions are even more dramatic. Peñarroya agriculture is simulated to experience 20 to 40 million $\mathrm{m}^{3}$ of unmet demand during the months of April through July in the each of the dry years in the Dry Cycle climate sequence. This volume that cannot be met

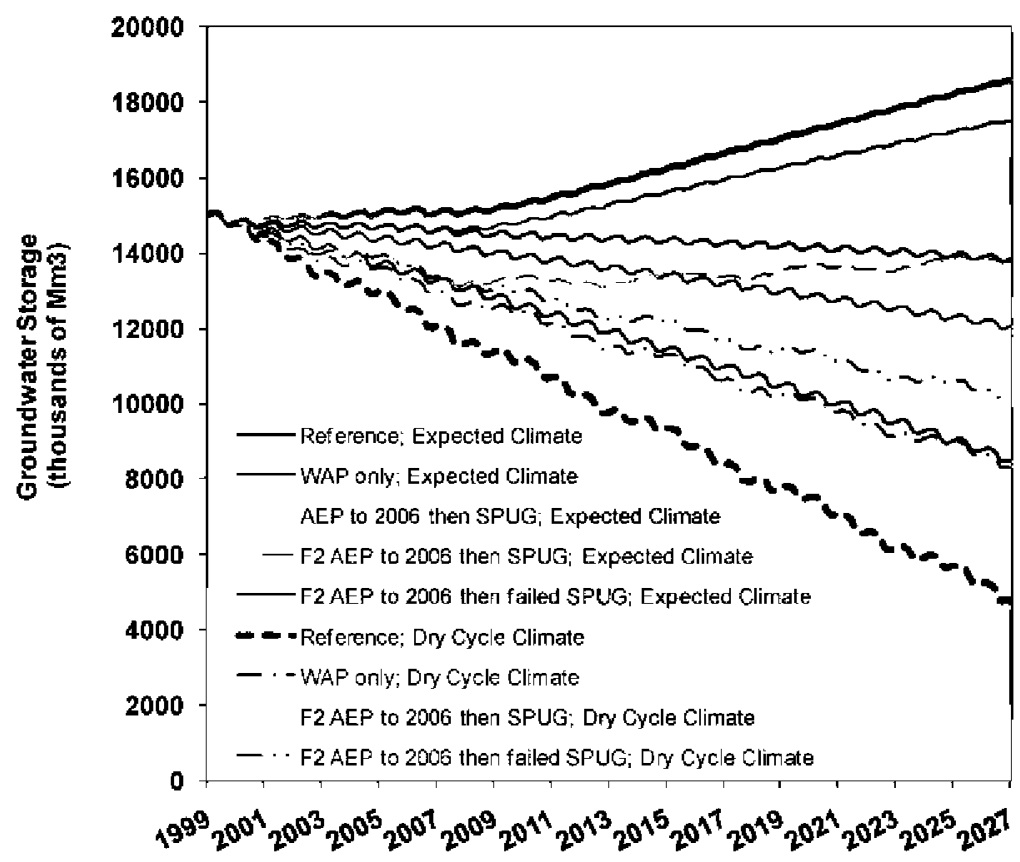

Notes: WAP (Water Abstraction Plan); AEP (Agro-Environmental Program, 50\% of water reduced and $100 \%$ of water reduced); SPUG (Special Plan for the Upper Guadiana).

Fig. 9. Potential trends in groundwater storage in the Upper Guadiana basin. 
by the reservoir storage under this climate scenario represents approximately $70 \%$ of its total water requirement during each of those months.

\section{Conclusions}

The analysis of economic and hydrology responses to water resource planning is a key element in robust policy development. This paper shows an essential progression in water management assessment from a baseline current examination to the analysis of economic and hydrology responses. Economic analysis seeks to represent how the current configuration of farms types might be altered under different water stress conditions, in response to economic shocks, as a result of water and agricultural policy interventions. It indicates critical adaptation thresholds that result in one farm being more exposed to environmental, economic and policy impacts than another. The hydrology analysis seeks to represent the short and long term responses of an aquifer system to these policy interventions and to climate variations.

The starting point for the analysis of water management regimes in the Spanish Upper Guadiana basin is a thorough description of the baseline farm economy and surveys and interviews with farmers throughout the region. This paper presents an innovative analysis that links this baseline to a farm-based economic modeling of policy-relevant scenarios. This micro-scale vision is then aggregated to the basin-level by means of a hydrology model (WEAP) coupled to the economic model by reproducing the same policy scenarios.

The economic and hydrology integrated modeling platform provides a novel and policy-relevant framework for the spatial and temporal analysis of water and agricultural policies under different climate scenarios. It permits the prediction of different policy outcomes across farm types (water stress impacts and adaptation), at basin's level (aquifer recovery), and along the policies' implementation horizon (short and long run).

In general, short term water conservation policies that are being implemented in the Upper Guadiana basin can contribute to reduce water consumption in the farms, but will not be able to achieve, in the aggregate, the recovery of the Western La Mancha aquifer. The desired target of the aquifer replenishing will be met only if the new regional water plan (SPUG) is fully implemented and the long-term environmental and social measures for reducing water abstractions are enforced (purchase of water rights, closing up unlicensed wells, legalization of selected illegal wells, reforestation and rainfed farming programs). However, the recovery objective will be difficult to meet in case of droughts in spite of the high resilience of groundwater to climate change impacts.

The successful implementation of the regional water plan is dependent on the farmers' willingness to sell their water rights at the prices offered. At prevailing prices, farms with permanent crops (vineyard) are less likely to sell their rights due to lower purchase prices and might question the feasibility of the program.

In general, water conservation policies that apply a strict quota system can achieve water use reductions at low public costs. However, these policies are likely to be opposed strongly by the farmers that bear the full burden and would entail high enforcement costs to the public authorities. Increasing the direct participation of stakeholders and stronger involvement in the decisions, as well as social learning activities, are strongly needed for the social acceptance of this type of policies. This type of analysis should be thoroughly considered in future studies.

on the other hand, water polices that include a quota system and an income compensation scheme (such as the agri-environmental programs) can achieve the programmed water conservation target, provided that a large proportion of farmers are willing to participate in the program. These policy programs generally have a higher social acceptance but are costly policies and costeffectiveness is low. Such programs conflict with the recently adopted EU Water Framework Directive that requires a costeffective evaluation of all program measures. Given that the new trends of agricultural policies encourage water-saving farming, a coordinated and integrated implementation of agricultural and water polices is a key element. It would ensure the dual objective of conserving groundwater resources and maintaining farm-based livelihoods at tolerable social costs. This will be best attained by avoiding contradictions, finding synergies and reinforcing common objectives.

In this context, the design and enforcement of well-balanced region-specific polices is one of the major tasks of policy makers for achieving successful water management policies. Then, in a multilevel perspective, the challenge facing the Spanish regional administration is to implement successfully both EU and regional water policies. At present, the environmental and participatory WFD requirements are providing incentives to better enforce water policies with a higher social acceptance, credibility and legitimization. Profiting from the impulse of these socially-based incentives is a challenge for water policy makers in Spain and elsewhere in the EU. In sum, the integrated vision of this example in which complex natural and human systems interact under a common research initiative could provide a valuable methodological illustration to inform water policy and water management decisions within settings of water-related conflicts worldwide.

\section{Acknowledgements}

The authors wish to acknowledge the two EU projects NEWATER 'New Approaches to Adaptive Water Management under Uncertainty' (FP6-2003-GOCE- 511179-2, 2005-2009) and SCENES 'Water Scenarios for Europe and for Neighboring States (FP6-2005-GOCE-4- 036822-2, 2007-2011) of the European Commission for providing funds for this research. The authors are also thankful to two anonymous reviewers for their careful review and valuable comments that have contributed significantly to the improvement of the manuscript.

\section{References}

Ahrends, H., Mast, M., Rodgers, Ch., Kunstmann, H., 2008. Coupled hydrologicaleconomic modeling for optimized irrigated cultivation in a semi-arid catchment of West Africa. Environmental Modelling \& Software 23, 385-395.

Albiac, J., Hanemann, M., Calatrava, J., Uche, J., Tapia, J., 2006. The rise and fall of the Ebro water transfer. Natural Resources Journal 46, 727-758.

Andreu, J., Solera, A., Paredes, J., Sánchez, S., 2006. Decision support systems for integrated water resources planning and management. In: Paper Presented in the International Workshop on Hydro-economic Modelling and Tools for the Implementation of the EU Water Framework Directive, Valencia, Spain.

Arriaza, M., Gómez-Limon, J.A., Upton, M., 2002. Local water markets for irrigation in southern Spain: A multicriteria approach. The Australian Journal of Agricultural and Resource Economics 46, 21-43.

Assaf, H., Saadeh, M., 2008. Assessing water quality management options in the Upper Litani Basin, Lebanon, using an integrated GIS-based decision support system. Environmental Modelling \& Software 23 (10-11), 1327-1337.

Baldock, D., Dwyer, J., Sumpsi, J.M., Varela-Ortega, C., Caraveli, H., Einschütz, S., Petersen, J.E., 2000. The Environmental Impacts of Irrigation in the European Union. Report of the European Commission. Brussels, Belgium.

Balkhausen, O., Banse, M., Grethe, H., 2008. Modelling CAP Decoupling in the EU: A Comparison of Selected Simulation Models and Results. Journal of Agricultural Economics 59, 57-71.

Bartolini, F., Bazzani, G.M., Gallerani, V., Raggi, M., Viaggi, D., 2007. The impact of water and agriculture policy scenarios on irrigated farming systems in Italy: An analysis based on farm level multi-attribute linear programming models. Agricultural Systems 93, 90-114.

Benoit, G., Comeau, A. (Eds.), 2005. A sustainable future for the Mediterranean: The Blue Plan's Environment and Development Outlook. Plan Bleu, Earthscan Publications Ltd., London, UK, p. 640.

Blanco-Gutiérrez, I., Varela-Ortega, C., Flichman, G., 2010. Cost-effectiveness of groundwater conservation measures: A multi-level analysis with policy implications. Agricultural Water Management, doi:10.1016/j.agwat.2010.10.013. 
Brouwer, R., Hofkes, M., 2008. Integrated hydro-economic modelling: Approaches, key issues and future research directions. Ecological Economics 66 (1), 16-22.

Calatrava, J., Garrido, A., 2005. Modelling water markets under uncertain water supply. European Review of Agricultural Economics 32, 119-142.

Challinor, A., Wheeler, T., Garforth, C., Craufurd, P., Kassam, A., 2007. Assessing the vulnerability of food crop systems in Africa to climate change. Climatic Change $83,381-399$.

CHG (Confederación Hidrográfica del Guadiana), 2006. Régimen de explotación para el año 2007 de la unidad hidrogeológica de la Mancha Occidental y de un perímetro adicional de la unidad hidrogeológica de la sierra de Altomira. CHG, Ciudad Real, Spain.

CHG (Confederación Hidrográfica del Guadiana), 2007a. Plan especial del Alto Guadiana. Documento de síntesis. Ministerio de Medio Ambiente, Madrid, Spain.

CHG (Confederación Hidrográfica del Guadiana), 2007b. Plan Especial de Sequía de la Cuenca del Guadiana. Badajoz, Spain.

CAWMA (Comprehensive Assessment of Water Management in Agriculture), 2007. Water for Food, Water for Life: A Comprehensive Assessment of Water Management in Agriculture. Earthscan and International Water Management Institute, London, UK and Colombo, Sri Lanka.

De Fraiture, C., 2007. Integrated water and food analysis at the global and basin level. An application of WATERSIM. Water Resources Management 21, $185-198$.

De Fraiture, C., Cai, X., Rosegrant, M., Molden, C., Amarasinghe, U., 2003. Addressing the unanswered questions in global water policy: A methodology framework. Irrigation and Drainage 52, 21-30.

EC(European Commission), 2000. Directive 2000/60/EC of the European Parliament and of the Council of 23 October 2000 establishing a framework for Community action in the field of water policy. Official Journal of the European Union L 327, Luxemburg.

EC(European Commission), 2009. Council Regulation(EC) No 73/2009 of 19 January 2009 establishing common rules for direct support schemes for farmers under the common agricultural policy and establishing certain support schemes for farmers, amending Regulations (EC) No 1290/2005, (EC) No 247/2006, (EC) No $378 / 2007$, and repealing Regulation (EC) No $1782 / 2003$. Official Journal of the European Union L 30, Luxemburg, pp. 16-99.

Gómez-Limon, J.A., Berbel, J., Arriaza, M., 2007. MCDM Farm System Analysis for public management of irrigated agriculture. In: Weintraub, A., Romero, C., Bjørndal, T., Epstein, R., Miranda, J. (Eds.), Handbook of Operations Research in Natural Resources. Springer US, Boston, MA, pp. 93-114.

Gómez-Limón, J.A., Riesgo, L., 2004. Irrigation water pricing: Differential impacts on irrigated farms. Agricultural Economics 31, 47-66.

Guan, D., Hubacek, K., 2008. A new and integrated hydro-economic accounting and analytical framework for water resources: A case study for North China. Journal of Environmental Management 88, 1200-1313.

Guerrero-García, H.R., Yúnez-Naude, A., Medellín-Azuara, J. (Eds.), 2008. El agua en México: consecuencias de las políticas de intervención en el sector. México: Fondo de Cultura Económica, p. 222.

Hanemann, W.H., 2006. The economic conception of water. In: Rogers, P.P., Llamas, M.R., Martinez-Cortina, L. (Eds.), Water Crisis: Myth or Reality. Taylor and Francis Plc., London, UK, pp. 61-91.

Harou, J., Pulido-Velázquez, M., Rosenberg, D.E., Medellín-Azuara, J., Lund, J.R., Howitt, R.E., 2009. Hydro-economic models: Concepts, design, applications, and future prospects. Journal of Hydrology 375, 627-643.

Hazell, P.B., Norton R.D., 1986. Mathematical programming for economic analysis in agriculture. Macmillan Publishing Company, New York, USA, p. 400.

Heinz, I., Pulido-Velázquez, M., Lund, J.R., Andreu, J., 2007. Hydro-economic modeling in river basin management: Implications and applications for the European Water Framework Directive. Water Resources Management 21, 1103-1125.

Iglesias, A., Quiroga, S., 2007. Measuring cereal production risk form climate variability agross geographical areas in Spain. Climate Research 34, 47-57.

Iglesias, A., Rosenzweig, C., Pereira, D., 2000. Agricultural impacts of climate in Spain: Developing tools for a spatial analysis. Global Environmental Change 10, 69-80.

Iglesias, E., 2001. Economía y gestiôn de las aguas subterrâneas: El caso del acuífero Mancha Occidental. Unpublished Ph.D. Thesis. Universidad Politécnica de Madrid, Madrid, Spain.

JCC-LM (Junta de Comunidades de Castilla La Mancha), 2006. Consejería de Agricultura y Medio Ambiente, Comunidad de Castilla-La Mancha, Toledo, Spain. [Online] URL: http://ww.jccm.es.

JCC-LM (Junta de Comunidades de Castilla-La Mancha), 1999. Programa de compensación de las rentas agrarias en las Unidades Hidrogeológicas de Mancha Occidental y Campo de Montiel. Consejería de Agricultura y Medio Ambiente, Comunidad de Castilla-La Mancha, Toledo, Spain.

Jenkins, M.W., Lund, J., Howitt, R., Draper, A., Msangi, S., Tanaka, S., Ritzema, R., Marques, G., 2004. Optimization of California's Water Supply System: Results and Insights. Journal of Water Resources Planning and Management 130 (4), 271-280.

Johansson, R.C., Tsur, Y., Roe, T.L., Doukkali, R., Dinar, A., 2002. Pricing irrigation water: A review of theory and practice. Water Policy 4 (2), 173-199.

Lanini, S., Courtois, N., Giraud, F., Petit, V., Rinaudo, J.D., 2004. Socio-hydrosystem modelling for integrated water-resources management: The Hêrault catchment case study, southern France. Environmental Modelling\& Software 19, 1011-1019.

Lévite, H., Sally, H., Cour, J., 2003. Water demand management scenarios in a waterstressed basin in South Africa: Application of the WEAP model. Physics and Chemistry of the Earth 28, 779-786.
Llamas, M.R., Martínez-Santos, P., 2006. Significance of the Silent Revolution of intensive groundwater use in world water policy. In: Rogers, P.P., Llamas, M.R., Martinez-Cortina, L. (Eds.), Water Crisis: Myth or Reality. Taylor and Francis Plc., London, UK, pp. 163-180.

Mainuddin, M., Kirby, M., Qureshi, M.E., 2007. Integrated hydrologic-economic modelling for analyzing water acquisition strategies in the Murray River Basin. Agricultural Water Management 93, 123-135.

Maneta, M.P., Torres, M.O., Wallender, W.W., Vosti, S., Howitt, R., Rodrigues, L. Bassoi, L.H., Panday, S., 2009. A spatially distributed hydroeconomic model to assess the effects of drought on land use, farm profits, and agricultural employment. Water Resources Research 45, W11412 (doi:10.1029/2008WR007534).

Martínez-Santos, P., De Stefano, L., Llamas, M.R., Martínez-Alfaro, P.E., 2008. Wetland restoration in the Mancha Occidental aquifer, Spain: A critical perspective on water, agricultural and environmental policies. Restoration Ecology 16(3), 511-521.

McCann, L., Colby, B., Easter, K.W., Kasterine, A., Kuperan, K.V., 2005. Transaction cost measurement for evaluating environmental policies. Ecological Economics $52,527-542$.

McKinney, D., Cai, X., Rosegrant, M.W., Ringler, C., Scott, C.A., 1999. Modeling water resources management at the basin level: Review and future directions. SWIM Paper No. 6. International Water Management Institute (IWMI), Colombo, Sri Lanka, p. 71.

Mejias P., Varela-Ortega C., Flichman G., 2004. Integrating agricultural policies and water policies under water supply and climate uncertainty. Water Resources Research 40, W07S03 (doi:10.1029/2003WR002877).

MIMAM (Ministerio de Medio Ambiente), 2006. Parques Nacionales. Madrid, Spain. Available online at http://reddeparquesnacionales.mma.es/

MOPTMA-CHG (Ministerio de Obras Públicas, Transportes y Medio AmbienteConfederación Hidrográfica del Guadiana), 1995. El problema hidráulico de la cuenca alta del Guadiana. Ciudad Real, Spain.

Moreno, J.M., 2005. A Preliminary Assessment of the Impacts in Spain due to the Effects of Climate Change. Final report prepared by Spanish Ministry of the Environment and Rural and Marine Affairs. ECCE Project. Madrid, Spain, p. 840

Mukherji, A., 2006. Is intensive use of groundwater a solution to world's water crisis? In: Rogers, P.P., Llamas, M.R., Martinez-Cortina, L. (Eds.), Water Crisis: Myth or Reality. Taylor and Francis Plc., London, UK, pp. 181-193.

Oñate J.J., Atance, I., Bardají, I., Llusia, D., 2007. Modelling the effects of alternative CAP policies for the Spanish high-nature value cereal-steppe farming systems, Agricultural Systems 94 (2), 247-260.

Provencher, B., Burt, O., 1994. A private property rights regime for the commons: The case for groundwater. American Journal of Agricultural Economics 76, 875888 .

Pulido-Velázquez, M., Andreu, J., Sahuquillo, A., Pulido-Velázquez, D., 2008. Hydroeconomic river basin modelling: The application of a holistic surface-groundwater model to assess opportunity costs of water use in Spain. Ecological Economics 66, 51-65.

Purkey, D., Thomas, G.A., Fullerton, D.K., Moench, M., Axelrad, L., 1998. Feasibility Study of a Maximal Program of Groundwater Banking. Report prepared by the Natural Heritage Institute, California, USA, p. 91

Purkey, D.R., Huber-Lee, A., Yates, D.N., Hanemann, M., Herrod-Julius, S., 2007. Integrating a climate change assessment tool into stakeholder-driven water management decision-making processes in California. Water Resources Management 21, 315-329.

Purkey, D.R., Joyce, B., Vicuna, S., Hanemann, M.W., Dale, L.L., Yates, D., Dracup, J.A. 2008. Robust analysis of future climate change impacts on water for agriculture and other sectors: A case study in the Sacramento Valley. Climatic Change 87 (1) $109-122$.

Qureshi, A.S., McCornick, P.G., Sarwar, A., Sharma, B.R., 2009. Challenges and Prospects of sustainable groundwater management in the Indus Basin, Pakistan. Water Resources Management 24 (8), 1551-1569.

Ramsar, 2006. The Ramsar Convention on Wetlands. Available online at http:// www.ramsar.org/.

Reidsma, P., Ewert, F., 2008. Regional farm diversity can reduce vulnerability of food production to climate change. Ecology and Society 13 (1), 38 [online] URL: http://www.ecologyandsociety.org/vol13/iss 1/art38/.

Rosegrant, M., Cai, X., Cline, S., 2002. World Water and Food to 2025: Dealing with Scarcity. International Food Policy Research Institute(IFPRI), Washington, DC, p. 338.

Schlager, E., López-Gunn, E., 2006. Collective systems for water management: Is the Tragedy of the Commons a myth? In: Rogers, P.P., Llamas, M.R., MartinezCortina, L. (Eds.), Water Crisis: Myth or Reality. Taylor and Francis Plc., London UK, pp. 43-58.

Schuyt, K.D., 2005. Economic consequences of wetland degradation for local populations in Africa. Ecological Economics 53, 177-190.

Seeman, J., Flichman, G., Scardigno, A., Steduto, P., 2007. Analysis of nitrate pollution control policies in the irrigated agriculture of Apulia Region (Southern Italy): A bio-economic modelling approach. Agricultural Systems 94 (2), 357-367.

SEI (Stockholm Environmental Institute), 2008. WEAP21 (Water Evaluation and Planning System). Stockholm Environment Institute and Tellus Institute, Boston, USA. Available online at http://www.weap21.org/.

Shah, T., Molden, D., Sakthivadivel, R., Seckler, D., 2000. The global groundwater situation: Overview of opportunities and challenges. Research Report Prepared by the International Water Management Institute (IWMI), Colombo, Sri Lanka.

Sieber J., Purkey D., 2007. User Guide for WEAP21 (Water Evaluation and Planning System). Stockholm Environment Institute, US Center, p. 219. 
Smit, B., McNabb, D., Smithers, J., 1996. Agricultural adaptation to climatic variation. Climate Change 33, 7-29.

Smit, B., Skinner, M.W., 2002. Adaptation options in agriculture to climate change: A typology. Mitigation and Adaptation Strategies for Global Change 7 (1), 85-114.

Szvetlana, A., Hanley, N., Dallimer, M., Gaston, K.J., Robertson, Ph., Wilson, P., Armsworth, P.R., 2010. The effect of decoupling on marginal agricultural systems: Implications for farm incomes, land use and upland ecology. Land Use 27, 550-563.

Turner, K., Georgiou, S., Clark, R., Brouwer, R., Burke, J., 2004. Economic valuation of water resources in agriculture. From the Sectoral to a Functional Perspective of Natural Resource Management. FAO Water Reports No. 27. Food and Agriculture Organization of the United Nations (FAO), Rome, Italy.

Varela-Ortega, C., 2007. Policy-driven determinants of irrigation development and environmental sustainability: a case study in Spain. In: Molle, F., Berkoff, J. (Eds.), Irrigation water pricing policy in context: exploring the gap between theory and practice. Comp.Asses.Wat.Mng, IWMI and CABI press, pp. 328-346.

Varela-Ortega, C., Blanco, I., Carmona, G., Esteve, P., 2006a. Field work report in the Upper Guadiana basin (Spain). Deliverable 1.7.5b (II), Newater Project ( $\mathrm{n}^{\circ}$ 511179-2) DG Research, EU Commission, Brussels, Belgium.

Varela-Ortega, C., Blanco, I., Carmona, G., Esteve, P., 2008. Stakeholder consultation and feedback meeting in the Guadiana basin (Spain). Presentation and dissemination of results. UPM Internal report, Newater Project ( $\left.n^{\circ} 511179-2\right)$ DG Research, EU Commission, Brussels, Belgium.

Varela-Ortega, C., Blanco, I., Swartz, C.H. Downing, T.E., 2009. Dealing with the tradeoff between water for nature and water for rural livelihoods in the presence of climate uncertainties: Lessons for water management. Paper presented at the XXVII Congress of the International Association of Agricultural
Economists (IAAE). The New Landscape of Global Agriculture. Beijing, China, August 2009. Available at: http://ageconsearch.umn.edu/bitstream/51420/2/ IAAE2009-paper454\%20\%28Varela\%20et\%20al\%29.pdf

Varela-Ortega, C., in press. The Water Policies in Spain: Balancing water for food and water for nature. In: Ingram, H., Garrido, A. (Eds.), Water for Food: Ouantity and Quality in a Changing World. Rosenberg International Forum on Water Policy. Routledge Publisher, Taylor and Francis Group, Abingdon, UK.

Varela-Ortega, C., Rapallo, R., Blanco, 1., 2006b. Adaptive management of water resources: Stakeholder participation for vulnerability and adaptation analysis using WEAP. Report on the Use of WEAP21 for Water Management in the Upper Guadiana Basin (Spain). Deliverable $1.7 .5 \mathrm{~b}(\mathrm{IV})$. Newater Project $\left(n^{\circ}\right.$ 511179-2) DG Research, EU Commission, Brussels, Belgium.

Varela-Ortega, C., Sagardoy, J.A., 2003. Analysis of irrigation water policies in Syria: current developments and future options. In: Fiorillo, C., Vercueil, J. (Eds.), Syrian Agriculture at the Crossroads. FAO series APED (Agriculture Policy and Economic Development) 8. Food and Agriculture Organization of the United Nations (FAO), Rome, Italy, pp. 335-359.

Varela-Ortega, C., Simó, A., Blanco, I., 2006c. The effects of alternative policy scenarios on Multifunctionality: A Case Study of Spain. ENARPRI Working paper 15. CEPS (Center for European Policy Studies), Brussels, Belgium, p. 47. (ISBN 929079-636-7)

Yates, D., Sieber, J., Purkey, D., Huber-Lee, A., 2005. WEAP21-A Demand-, Priorityand Preference-Driven Water Planning Model: Part 1, Model Characteristics. Water International 30, 487-500.

Zekri, S., 2009. Controlling groundwater pumping online. Journal of Environmental Management 90, 3581-3588. 